\title{
Spatiotemporal Variations and Factors of Air Quality in Urban Central China during 2013-2015
}

\author{
Mao Mao ${ }^{1}$, Xiaolin Zhang * ${ }^{*}$, Yamei Shao and Yan Yin \\ Key Laboratory for Aerosol-Cloud-Precipitation of China Meteorological Administration, School of Atmospheric \\ Physics, Nanjing University of Information Science \& Technology, Nanjing 210044, China; \\ mmao@nuist.edu.cn (M.M.); shaoyamei@mail.iap.ac.cn (Y.S.); yinyan@nuist.edu.cn (Y.Y.) \\ * Correspondence: xlnzhang@nuist.edu.cn; Tel.: +86-25-5869-9773
}

Received: 28 November 2019; Accepted: 25 December 2019; Published: 28 December 2019

\begin{abstract}
Spatiotemporal behaviors of particulate matter $\left(\mathrm{PM}_{2.5}\right.$ and $\left.\mathrm{PM}_{10}\right)$ and trace gases $\left(\mathrm{SO}_{2}\right.$, $\mathrm{NO}_{2}, \mathrm{CO}$, and $\mathrm{O}_{3}$ ) in Hefei during the period from December 2013 to November 2015 are investigated. The mean annual $\mathrm{PM}_{2.5}\left(\mathrm{PM}_{10}\right)$ concentrations are $89.1 \pm 59.4 \mu \mathrm{g} / \mathrm{m}^{3}\left(118.9 \pm 66.8 \mu \mathrm{g} / \mathrm{m}^{3}\right)$ and $61.6 \pm$ $32.2 \mu \mathrm{g} / \mathrm{m}^{3}\left(91.3 \pm 40.9 \mu \mathrm{g} / \mathrm{m}^{3}\right)$ during 2014 and 2015, respectively, remarkably exceeding the Chinese Ambient Air Quality Standards (CAAQS) grade II. All trace gases basically meet the requirements though $\mathrm{NO}_{2}$ and $\mathrm{O}_{3}$ have a certain upward trend. Old districts have the highest pollution levels, followed by urban periphery sites and new districts. Severe haze pollution occurs in Hefei, with frequent exceedances in particulate matter with 178 (91) days in 2014 (2015). The abnormal $\mathrm{PM}_{2.5}$ concentrations in June 2014 attributed to agricultural biomass burning from moderate resolution imaging spectroradiometry (MODIS) wildfire maps and aerosol optical depth (AOD) analysis. $\mathrm{PM}_{2.5}$ is recognized as the major pollutant, and a longer interspecies relationship is found between $\mathrm{PM}_{2.5}$ and other criteria pollutants for episode days as compared to non-episode days. The air pollution in Hefei tends to be influenced by local primary emissions, secondary formation, and regional transport from adjacent cities and remote regions. Most areas of Anhui, southern Jiangsu, northern Zhejiang, and western Shandong are identified as the common high-potential source regions of $\mathrm{PM}_{2.5}$. Approximately 9.44 and 8.53 thousand premature mortalities are attributed to $\mathrm{PM}_{2.5}$ exposure in 2014 and 2015 . The mortality benefits will be $32 \%(24 \%), 47 \%(41 \%), 70 \%(67 \%)$, and $85 \%(83 \%)$ of the total premature mortalities in 2014 (2015) when $\mathrm{PM}_{2.5}$ concentrations meet the CAAQS grade II, the World Health Organization (WHO) IT-2, IT-3, and Air Quality Guideline, respectively. Hence, joint pollution prevention and control measures need to be strengthened due to pollutant regional diffusion, and much higher health benefits could be achieved as the Hefei government adopts more stringent WHO guidelines for $\mathrm{PM}_{2.5}$.
\end{abstract}

Keywords: particulate matter; pollution sources; premature mortality; trace gas; PSCF/CWT

\section{Introduction}

In recent decades, China is facing severe air pollution with the booming economic growth and dramatic increase in energy consumption [1,2]. Health burden attributable to particulate matter (PM) has become a matter of public concern [3-6]. About 1.3 million deaths each year in China were attributable to ambient $\mathrm{PM}_{2.5}$ (PM with an aerodynamic diameter less than $2.5 \mu \mathrm{m}$ ) exposure [7]. It is necessary for us to understand the characteristics, sources, and influencing factors of pollutants to alleviate air pollution for health sake.

The government has formulated and promulgated a series of standards, laws, and regulations to reduce air pollutant emissions and improve environment quality [8]. The Chinese Ministry of Environmental Protection has issued air pollution index (API) starting from June 2000 in major cities, 
and the pollutants involve in the evaluation including $24 \mathrm{~h}$ average concentrations of ground measured sulfur dioxide $\left(\mathrm{SO}_{2}\right)$, nitrogen dioxide $\left(\mathrm{NO}_{2}\right)$, and $\mathrm{PM}_{10}$ ( $\mathrm{PM}$ with an aerodynamic diameter less than $10 \mu \mathrm{m})(\mathrm{http}: / /$ datacenter.mep.gov.cn/). The index is published only once a day, unable to accurately assess air quality level. Subsequently, $\mathrm{PM}_{2.5}$, carbon monoxide $(\mathrm{CO})$, and $8 \mathrm{~h}$ peak ozone $\left(\mathrm{O}_{3} 8 \mathrm{~h}\right)$ as the routine monitoring pollutants are adopted into the newly revised Chinese Ambient Air Quality Standards (CAAQS, GB3095-2012) by the China State Council on February 2012 [9]. The real-time hourly average concentration of six criteria of air pollutants and associated air quality index (AQI) are released for public scrutiny and scientific research [10].

Numerous studies of air pollution are implemented in China, especially for some representative megalopolis, such as Beijing, Shanghai, Guangzhou, Nanjing, and abundant observation data and research results have been obtained [11-17]. On the contrary, in Hefei (30.57-32.32 $\left.{ }^{\circ} \mathrm{N}, 116.41-117.58^{\circ} \mathrm{E}\right)$, the capital city of Anhui Province, central China, only a few sole researches of air pollution characteristics have been sporadically conducted to date. Huang et al. analyzed daily $\mathrm{PM}_{10}$ and visibility data in 2001-2012 to investigate the air quality status as well as the long-term pollution trends in the city of Hefei [18]. Zhang et al. evaluated the temporal variation of black carbon aerosols with year-round measurements $[19,20]$. Furthermore, the aerosol radiative characteristics were also evaluated to classify severe brown haze episodes in Hefei [21]. Hong et al. examined the influence of haze on the chemistry of atmospheric mercury on haze days [22]. Acute air pollution exposure was significantly associated with cardiovascular morbidity risk [23]. Hu et al. investigated particle-associated polycyclic aromatic hydrocarbons and assessed the health risks with the index of toxic equivalent concentration [24]. Heavy metal elements $(\mathrm{S}, \mathrm{Zn}, \mathrm{Cu}$, and $\mathrm{Pb}$ ) took up a large proportion of the overall PM concentrations in Hefei [25]. The rapid economic development has caused unoptimistic air condition in Hefei during recent years.

To the best of our knowledge, related studies of six criteria pollutants and corresponding influence factors in Hefei are still lacking so far. To fill up the research gap, the major objectives of this work are organized as follows: (1) to reveal the characteristics of six criteria pollutants, including $\mathrm{NO}_{2}$, $\mathrm{SO}_{2}, \mathrm{CO}, \mathrm{O}_{3}, \mathrm{PM}_{2.5}$, and $\mathrm{PM}_{10}$ and their annual, seasonal, monthly, and diurnal variations. (2) to investigate interspecies relationship and the relationship between pollutants and meteorological elements. (3) to identify the transport pathway and regional potential source contributions of PM based on the cluster analysis of backward trajectories, the potential source contribution function (PSCF) and concentration-weighted trajectory (CWT) models. (4) to estimate premature mortality ( $\triangle$ Mort) due to $\mathrm{PM}_{2.5}$ exposure and potential mortality benefits in scenarios where $\mathrm{PM}_{2.5}$ concentrations in Hefei meet the CAAQS grade II, the World Health Organization (WHO) interim target (IT)-2, IT-3, and Air Quality Guideline (AQG) with integrated exposure-response (IER) function from December 2013 to November 2015. The new findings will be helpful to understand the current situation of environmental quality, enhance the environmental awareness of the general public, and enable new perspectives on how to formulate effective incentives to retrofit air pollution control strategy in central China if necessarily in time.

\section{Data and Methodology}

Hefei is an inland medium-sized city situated in the west of the Yangtze River Delta (YRD). According to the 2015 Statistical Bulletin of Hefei, it has a permanent population of approximately 7.8 million, an occurrence of 1.2 million vehicles, and a gross domestic product (GDP) of 566.0 billion yuan. It is categorized as being in the transitional area between the temperate and subtropical zones with hot humid summer and cold dry winter. The real-time hourly average concentrations of six criteria pollutants from December 2013 to November 2015 in Hefei were downloaded from Chinese Environmental Protection Bureau (http://www.cnemc.cn). Two-year monitoring data are employed in this study, and the period from December 2013 to November 2014 represents the year 2014 while the period from December 2014 to November 2015 represents the year 2015. Figure 1 illustrates the location of Hefei and air quality monitoring stations. The ten monitoring sites are: Luyang District (LD; 


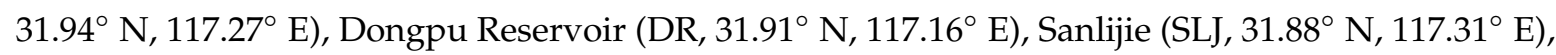
Amber Villa $\left(\mathrm{AV}, 31.87^{\circ} \mathrm{N}, 117.26^{\circ} \mathrm{E}\right)$, Yangtze River Road (YRR, 31.86 $\left.{ }^{\circ} \mathrm{N}, 117.25^{\circ} \mathrm{E}\right)$, Yaohai District $\left(\mathrm{YD}, 31.86^{\circ} \mathrm{N}, 117.34^{\circ} \mathrm{E}\right)$, High-tech Zone $\left(\mathrm{HT}, 31.85^{\circ} \mathrm{N}, 117.12^{\circ} \mathrm{E}\right)$, Baohe District $\left(\mathrm{BD}, 31.80^{\circ} \mathrm{N}\right.$, $\left.117.30^{\circ} \mathrm{E}\right)$, Pearl Plaza (PP, 31.78 $\left.\mathrm{N}, 117.20^{\circ} \mathrm{E}\right)$, and Binhu New Zone (BN, $\left.31.74^{\circ} \mathrm{N}, 117.28^{\circ} \mathrm{E}\right)$. DR is a large-scale reservoir used for flood control with no nearby emission sources, representing background levels for the region. In this study, the 8 h, 24 h, or daily, monthly, seasonal, and annual concentrations of air pollutants were calculated by averaging the hourly data from all of the monitoring stations. The surface meteorological observations were obtained from Hefei Meteorological Bureau.
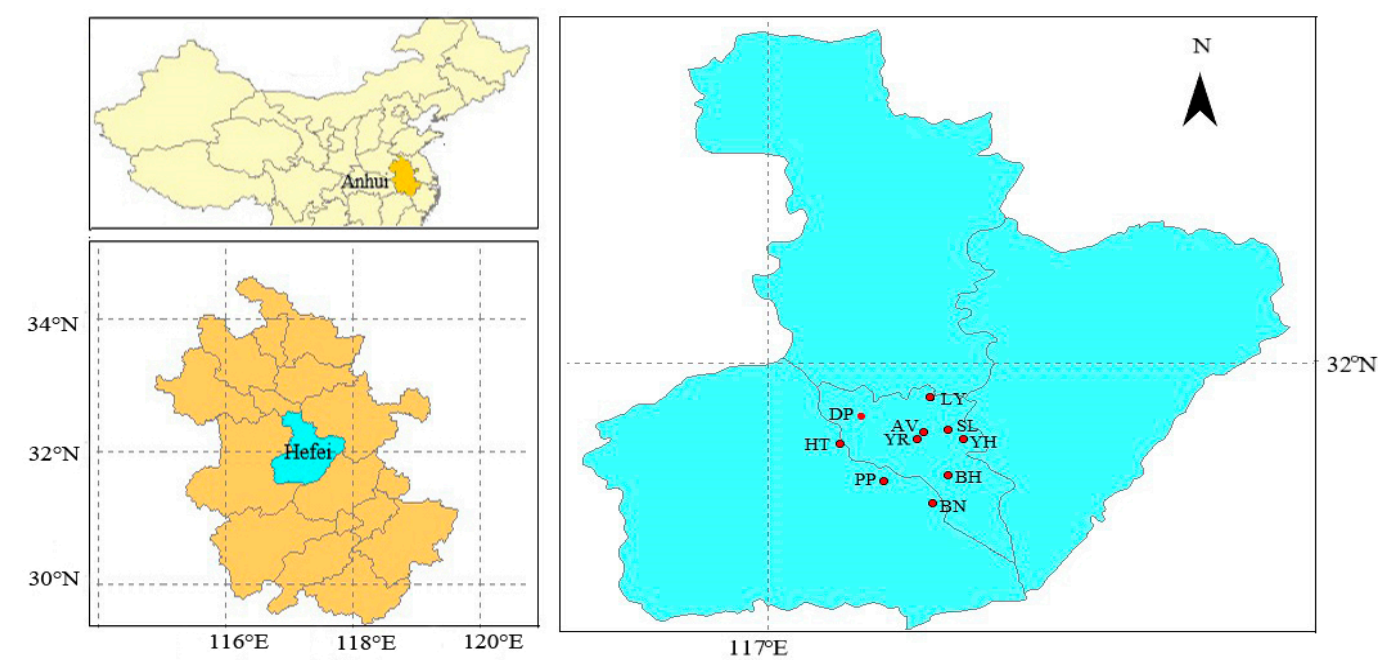

Figure 1. The location of Anhui Province (up-left), Hefei (down-left), and 10 air quality stations of Hefei (right).

To determine the direction where the airborne masses reached the central location of Hefei $\left(31.86^{\circ} \mathrm{N}, 117.25^{\circ} \mathrm{E}\right)$ qualitatively, $72 \mathrm{~h}$ backward trajectories were computed by using the Hybrid Single Particle Lagrange Integrated Trajectory (HYSPLIT)-4 model [26,27]. The PSCF model combines the results of backward-trajectory (8 times per day, 0:00, 3:00, 6:00, 9:00, 12:00, 15:00, 18:00, and 21:00 UTC) for reflecting the proportion of polluted trajectories. The CWT model is applied to weight trajectories with related $\mathrm{PM}_{2.5}$ concentrations for identifying the relative contribution of different source areas $[28,29]$. Areas with high PSCF/CWT values are supposed to be potential geographic origins of $\mathrm{PM}_{2.5}$. IER model is utilized to analyze the impact of long-term outdoor $\mathrm{PM}_{2.5}$ exposure on the $\Delta$ Mort $[30,31]$. The cumulative deaths caused by stroke (STR, including ischemic and hemorrhagic stroke), ischemic heart disease (IHD), lung cancer (LC), and chronic obstructive pulmonary disease (COPD) are considered as the total number of $\Delta$ Mort. For the detailed 'Date and Methodology' see the Supporting Information.

\section{Results and Discussion}

\subsection{Annual Variation}

The annual mean $\mathrm{PM}_{2.5}\left(\mathrm{PM}_{10}\right)$ concentrations are $89.1 \pm 59.4 \mu \mathrm{g} / \mathrm{m}^{3}\left(118.9 \pm 66.8 \mu \mathrm{g} / \mathrm{m}^{3}\right)$ and $61.6 \pm 32.2 \mu \mathrm{g} / \mathrm{m}^{3}\left(91.3 \pm 40.9 \mu \mathrm{g} / \mathrm{m}^{3}\right)$ during 2014 and 2015, respectively (Table 1), all of which remarkably exceed the CAAQS grade II $\left(\mathrm{PM}_{2.5}\right.$ of $35 \mu \mathrm{g} / \mathrm{m}^{3}$ and $\mathrm{PM}_{10}$ of $70 \mu \mathrm{g} / \mathrm{m}^{3}$ for annual average) and WHO guideline $\left(\mathrm{PM}_{2.5}\right.$ of $10 \mu \mathrm{g} / \mathrm{m}^{3}$ and $\mathrm{PM}_{10}$ of $20 \mu \mathrm{g} / \mathrm{m}^{3}$ for annual average) [32]. The standard deviation in 2014 is uniformity higher than that in 2015, which may be attributed to heavy atmospheric pollution during the period of the former. In 2008, the average annual $\mathrm{PM}_{10}$ concentration is $126 \mu \mathrm{g} / \mathrm{m}^{3}$, which is more serious than statistics in this work [18]. Compared to $\mathrm{PM}_{2.5}$ levels in the key cities of YRD, the mean concentration of $\mathrm{PM}_{2.5}$ in Hefei from December 2013 to November 2015 is higher than 
those in shanghai $\left(52 \mu \mathrm{g} / \mathrm{m}^{3}\right)$, Nanjing $\left(65 \mu \mathrm{g} / \mathrm{m}^{3}\right)$, Suzhou $\left(62 \mu \mathrm{g} / \mathrm{m}^{3}\right)$, Wuxi $\left(64 \mu \mathrm{g} / \mathrm{m}^{3}\right)$, Hangzhou $\left(61 \mu \mathrm{g} / \mathrm{m}^{3}\right)$, Ningbo $\left(45 \mu \mathrm{g} / \mathrm{m}^{3}\right)$, and Wuhu $\left(62 \mu \mathrm{g} / \mathrm{m}^{3}\right)$ [33]. Additionally, the annual mean concentration of $\mathrm{PM}_{2.5}$ in Hefei is lower than or similar with those in Beijing $\left(83 \mu \mathrm{g} / \mathrm{m}^{3}\right)$, Wuhan $\left(76 \mu \mathrm{g} / \mathrm{m}^{3}\right)$, Tianjin $\left(77 \mu \mathrm{g} / \mathrm{m}^{3}\right)$, and Jinan $\left(88 \mu \mathrm{g} / \mathrm{m}^{3}\right)$ while much higher than most coastal cities of China, including Dalian $\left(50 \mu \mathrm{g} / \mathrm{m}^{3}\right)$, Qingdao $\left(55 \mu \mathrm{g} / \mathrm{m}^{3}\right)$, Guangzhou $\left(44 \mu \mathrm{g} / \mathrm{m}^{3}\right)$, Xiamen $\left(33 \mu \mathrm{g} / \mathrm{m}^{3}\right)$, and Shenzhen $\left(33 \mu \mathrm{g} / \mathrm{m}^{3}\right)$ in China [33]. Concerning gaseous pollution, average annual $\mathrm{SO}_{2}, \mathrm{NO}_{2}, \mathrm{CO}$, and $\mathrm{O}_{3}$ concentrations are $30.2(17.3), 28.2(31.0), 1.1 \times 10^{3}\left(1.0 \times 10^{3}\right)$, and $50.4(64.8) \mu \mathrm{g} / \mathrm{m}^{3}$ in Hefei during $2014(2015)$, respectively. All trace gases basically meet CAAQS Grade II, further legislation and laws should be strengthened to restrain PM concentrations.

Table 1. Summary of air quality index (AQI) and the concentrations of six criteria air pollutants with standard deviations in Hefei (units are $\mu \mathrm{g} / \mathrm{m}^{3}$ for $\mathrm{PM}_{2.5}, \mathrm{PM}_{10}, \mathrm{NO}_{2}, \mathrm{SO}_{2}$, and $\mathrm{O}_{3}$, and $\mathrm{mg} / \mathrm{m}^{3}$ for $\mathrm{CO}$ ).

\begin{tabular}{ccccccccc}
\hline & Year & AQI & $\mathbf{P M}_{\mathbf{2 . 5}}$ & $\mathbf{P M}_{\mathbf{1 0}}$ & $\mathbf{S O}_{\mathbf{2}}$ & $\mathbf{N O}_{\mathbf{2}}$ & $\mathbf{C O}$ & $\mathbf{O}_{3}$ \\
\hline \multirow{2}{*}{ Annual } & 2014 & $118.1 \pm 68.6$ & $89.1 \pm 59.4$ & $118.9 \pm 66.8$ & $30.2 \pm 10.6$ & $28.2 \pm 11.1$ & $1.1 \pm 0.5$ & $50.4 \pm 18.8$ \\
& 2015 & $86.6 \pm 38.1$ & $61.6 \pm 32.2$ & $91.3 \pm 40.9$ & $17.3 \pm 8.8$ & $31.0 \pm 10.6$ & $1.0 \pm 0.3$ & $64.8 \pm 29.4$ \\
\hline \multirow{2}{*}{ Spring } & 2014 & $100.8 \pm 29.1$ & $73.5 \pm 22.7$ & $112.6 \pm 52.7$ & $18.2 \pm 5.8$ & $29.8 \pm 7.4$ & $0.9 \pm 0.2$ & $56.9 \pm 14.9$ \\
& 2015 & $86.9 \pm 26.7$ & $61.2 \pm 23.2$ & $96.7 \pm 33.4$ & $19.2 \pm 6.3$ & $26.9 \pm 8.8$ & $1.0 \pm 0.3$ & $61.1 \pm 18.1$ \\
\hline \multirow{2}{*}{ Summer } & 2014 & $93.6 \pm 45.0$ & $68.7 \pm 38.2$ & $101.7 \pm 47.9$ & $14.4 \pm 6.4$ & $20.5 \pm 6.0$ & $1.0 \pm 0.3$ & $63.9 \pm 21.0$ \\
& 2015 & $63.6 \pm 21.3$ & $41.3 \pm 19.1$ & $69.8 \pm 28.2$ & $9.5 \pm 4.0$ & $27.7 \pm 7.0$ & $0.9 \pm 0.2$ & $87.0 \pm 24.6$ \\
\hline \multirow{2}{*}{ Autumn } & 2014 & $101.6 \pm 54.9$ & $74.8 \pm 46.9$ & $112.0 \pm 60.9$ & $18.1 \pm 6.1$ & $25.9 \pm 9.3$ & $1.0 \pm 0.3$ & $42.0 \pm 15.6$ \\
& 2015 & $83.5 \pm 33.1$ & $59.2 \pm 27.6$ & $90.7 \pm 39.3$ & $13.6 \pm 5.1$ & $37.9 \pm 13.0$ & $1.1 \pm 0.3$ & $75.3 \pm 30.9$ \\
\hline \multirow{2}{*}{ Winter } & 2014 & $178.3 \pm 92.2$ & $141.2 \pm 81.6$ & $150.4 \pm 89.4$ & $30.7 \pm 14.0$ & $37.0 \pm 13.6$ & $1.5 \pm 0.7$ & $38.5 \pm 9.3$ \\
& 2015 & $113.0 \pm 48.9$ & $84.5 \pm 39.9$ & $108.8 \pm 50.2$ & $27.1 \pm 7.4$ & $31.9 \pm 9.3$ & $1.1 \pm 0.3$ & $35.3 \pm 10.6$ \\
\hline
\end{tabular}

\subsection{Seasonal and Monthly Variations}

To better study the temporal changes of pollutants, the corresponding data are divided into four seasons. In general, the mean concentrations of pollutants except $\mathrm{O}_{3}$ exhibited consistent seasonal variations, with similar magnitude in spring and autumn, lower concentrations in summer, and higher values occurring in winter (Table 1).

In winter, high concentrations of pollutants are attributable to the extra primary emissions and secondary formation of $\mathrm{PM}_{2.5}$ as the coal burning for power generation during this season. Moreover, the variations in pollution concentrations are affected by meteorological factors. Unfavorable diffusion conditions such as lower rainfall, more frequent calm winds, and the prevalence of cold high-pressure system induce pollutant accumulation in a shallow layer with descending air motions [34,35]. Especially, December $\left(179.6 \pm 85.9 \mu \mathrm{g} / \mathrm{m}^{3}\right.$ for $\mathrm{PM}_{2.5}$ and $195.0 \pm 84.3 \mu \mathrm{g} / \mathrm{m}^{3}$ for $\left.\mathrm{PM}_{10}\right)$ and January $\left(101.6 \pm 43.9 \mu \mathrm{g} / \mathrm{m}^{3}\right.$ for $\mathrm{PM}_{2.5}$ and $120.9 \pm 59.2 \mu \mathrm{g} / \mathrm{m}^{3}$ for $\left.\mathrm{PM}_{10}\right)$ are the 'worst' months for PM concentrations in 2014 and 2015, respectively (Figure 2a,b). In addition, prevailing winds carry air pollutants from more serious areas to the sampling site, resulting in air quality degradation in winter.

In summer, the corresponding precipitation accounts for nearly $50 \%$ of the annual precipitation (Table 2), and the increased mixed layer height and wet scavenging are conducive to pollutant dispersion. Nevertheless, the abnormal concentrations of $\mathrm{PM}_{2.5}$ are seen in June 2014 (Figure 2a), presumably caused by local straw burning. The information of dense fire points observed based on moderate resolution imaging spectroradiometry (MODIS) satellite [36] in Hefei and its surroundings could favor this viewpoint (Figure 3). As a big agricultural province, large-scale straw incineration is very common in rural areas of Anhui during summer and autumn. Numerous PM and gaseous contaminants are produced by incomplete combustion of straw residue in the open fields. After a series of supportive policies bound up with straw burning ban such as mechanization of straw chopping and returning to field are introduced by policy-makers, the air quality of Hefei improves obviously in June 2015. August $\left(54.1 \pm 20.2 \mu \mathrm{g} / \mathrm{m}^{3}\right.$ for $\mathrm{PM}_{2.5}$ and $82.8 \pm 31.5 \mu \mathrm{g} / \mathrm{m}^{3}$ for $\mathrm{PM}_{10}$ in $2014 ; 39.1 \pm 15.2 \mu \mathrm{g} / \mathrm{m}^{3}$ for $\mathrm{PM}_{2.5}$ and $74.2 \pm 24.3 \mu \mathrm{g} / \mathrm{m}^{3}$ for $\mathrm{PM}_{10}$ in 2015) is the 'cleanest' month for PM concentrations for both 2014 and 2015 identically. 

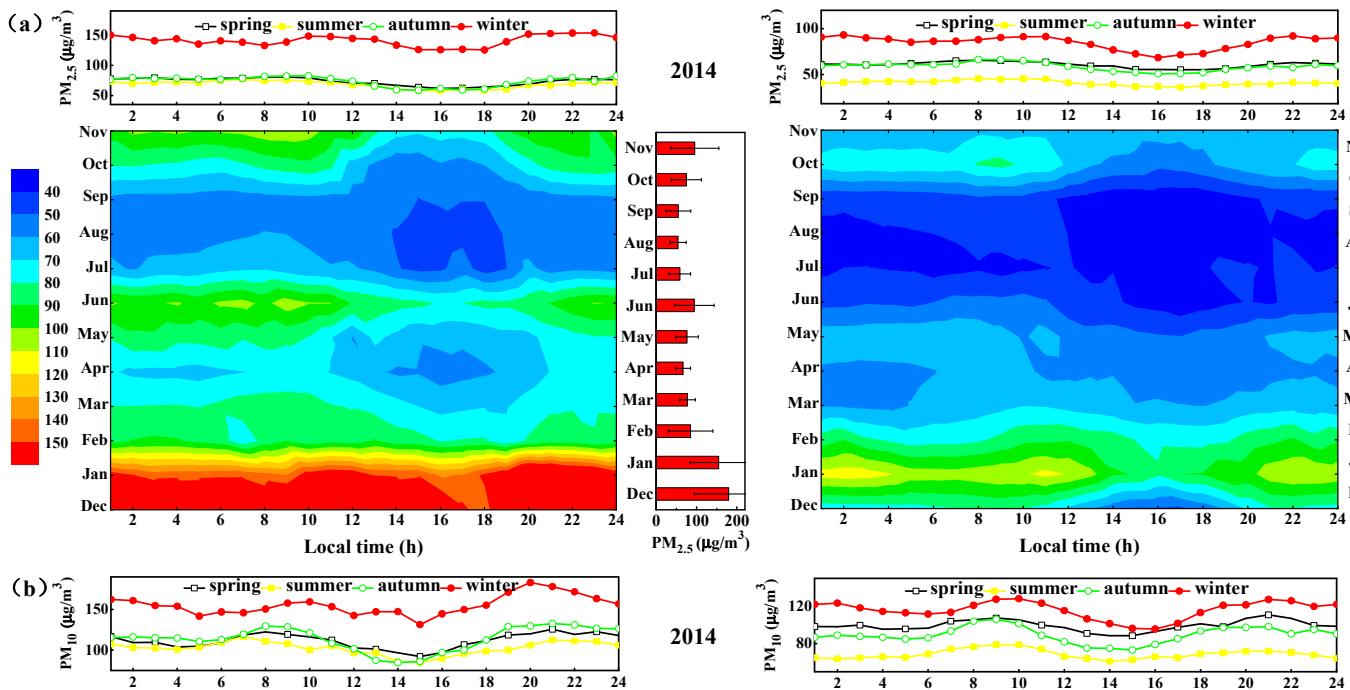

2014
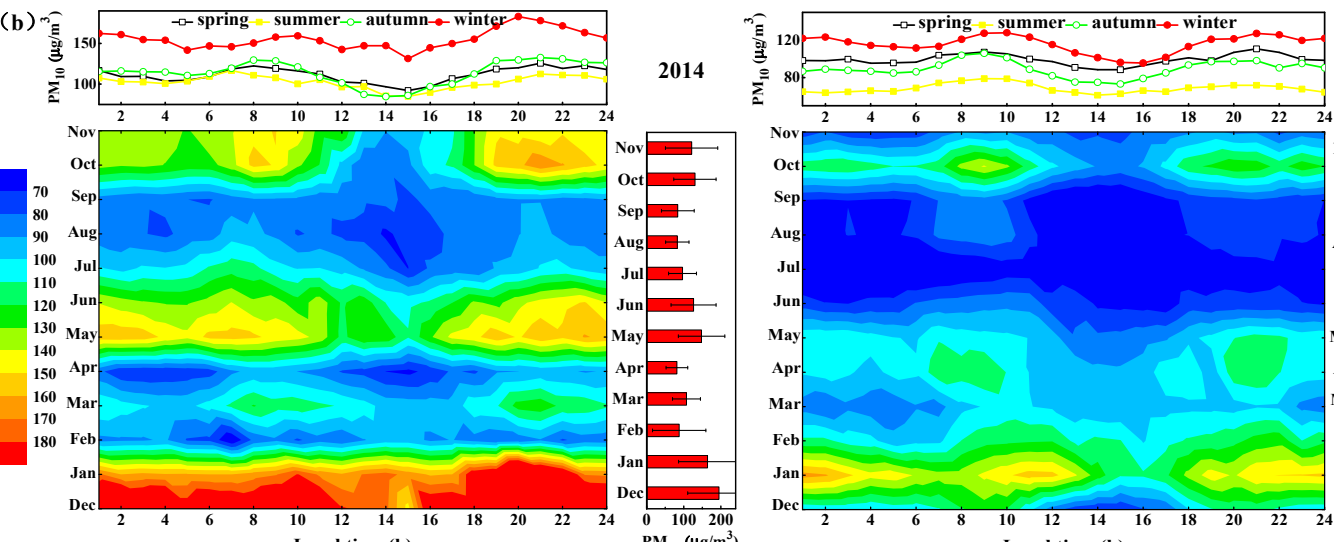

2015
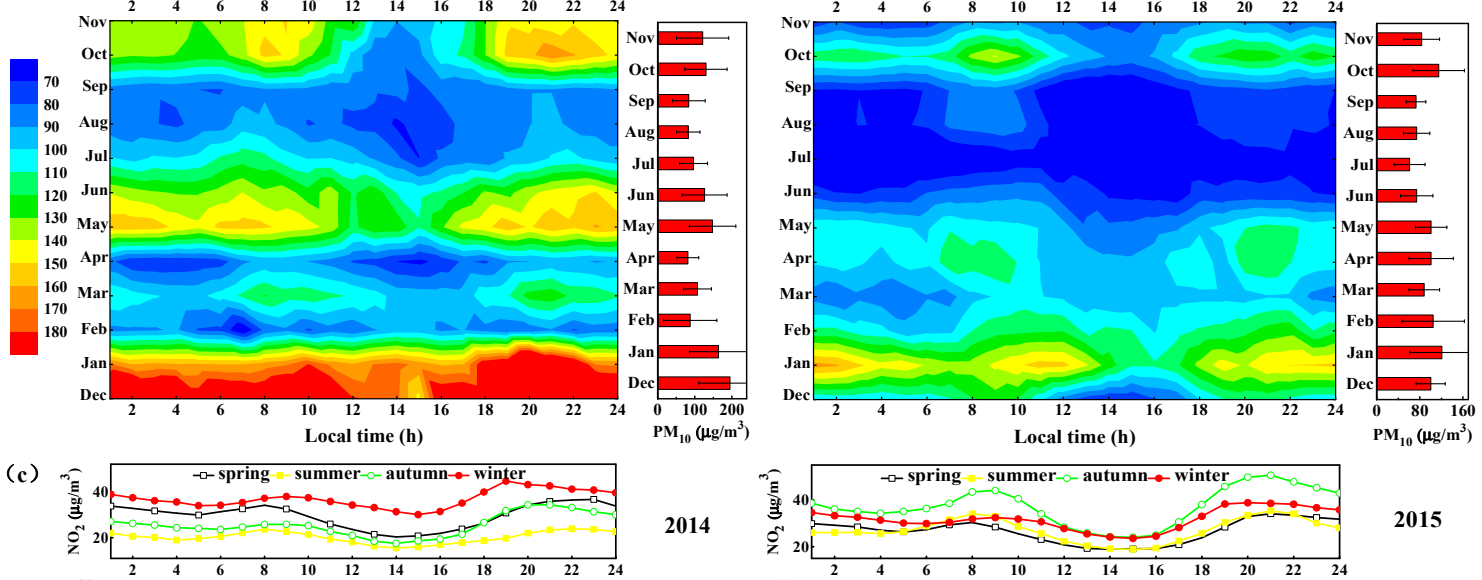

$\mathrm{PM}_{10}\left(\mu \mathrm{g} / \mathrm{m}^{3}\right)$

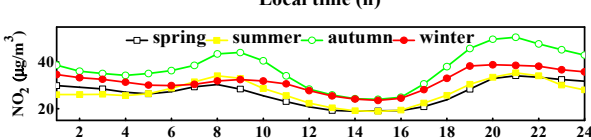

2015
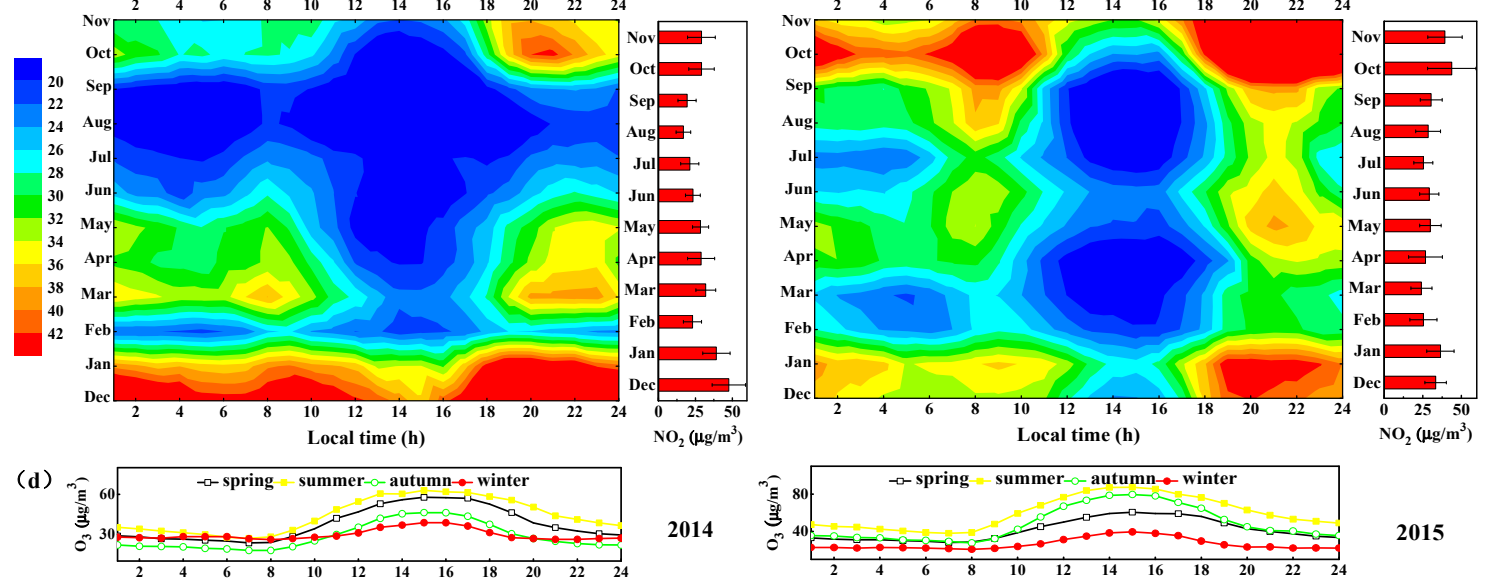

2014

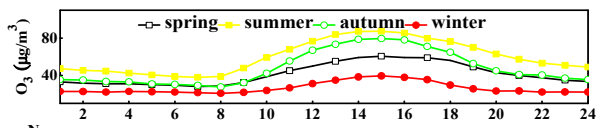

2015
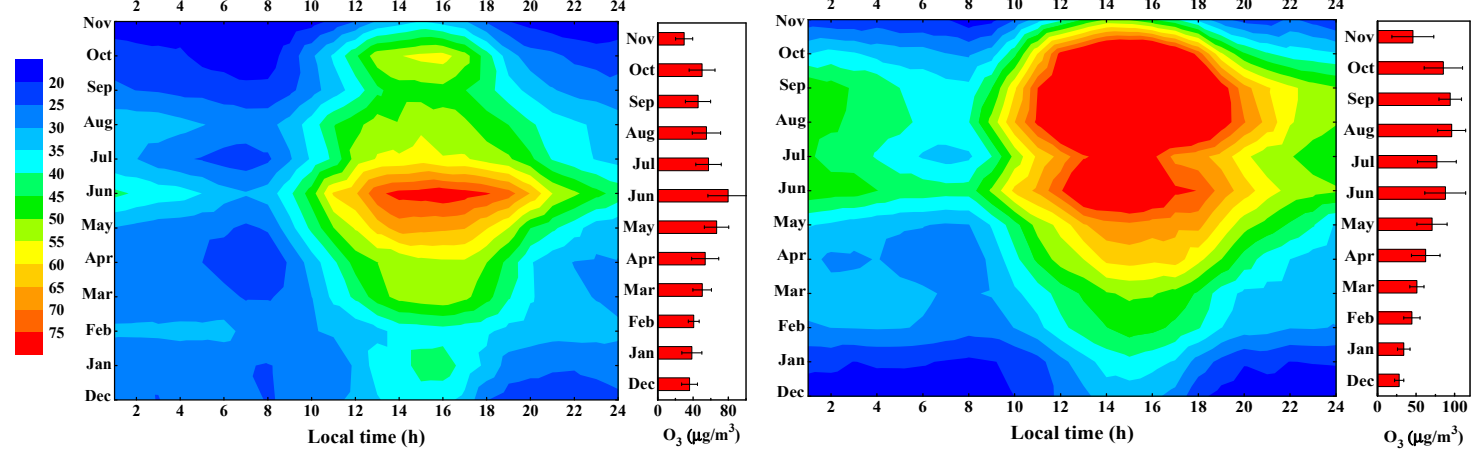

Figure 2. Diurnal variations of $\mathrm{PM}_{2.5}(\mathbf{a}), \mathrm{PM}_{10}(\mathbf{b}), \mathrm{NO}_{2}(\mathbf{c})$, and $\mathrm{O}_{3}(\mathbf{d})$. 
Table 2. Statistics of general meteorological parameters at Hefei *.

\begin{tabular}{|c|c|c|c|c|c|c|c|c|}
\hline $\begin{array}{c}\text { Meteorological } \\
\text { Parameters }\end{array}$ & Year & Total & Spring & Summer & Autumn & Winter & Non-Episode & Episode \\
\hline \multirow{2}{*}{$\mathrm{T}\left({ }^{\circ} \mathrm{C}\right)$} & 2014 & 16.5 & 17.1 & 26.3 & 18.0 & 4.4 & \multirow{2}{*}{18.6} & \multirow{2}{*}{13.5} \\
\hline & 2015 & 16.9 & 16.8 & 26.4 & 17.8 & 5.5 & & \\
\hline \multirow{2}{*}{ RH (\%) } & 2014 & 76 & 71 & 81 & 78 & 73 & \multirow{2}{*}{76} & \multirow{2}{*}{73} \\
\hline & 2015 & 74 & 72 & 80 & 77 & 67 & & \\
\hline \multirow{2}{*}{ WS (m/s) } & 2014 & 1.9 & 2.2 & 1.8 & 1.9 & 1.9 & \multirow{2}{*}{2.1} & \multirow{2}{*}{1.8} \\
\hline & 2015 & 2.0 & 2.0 & 2.1 & 1.9 & 2.0 & & \\
\hline \multirow{2}{*}{ Pre $(\mathrm{mm})$} & 2014 & 1237 & 298 & 546 & 247 & 146 & \multirow{2}{*}{2200} & \multirow{2}{*}{334} \\
\hline & 2015 & 1297 & 325 & 673 & 196 & 103 & & \\
\hline
\end{tabular}

* Note: mean values for air temperature (T), relative humidity (RH), wind speed (WS), accumulated value of precipitation (Pre).

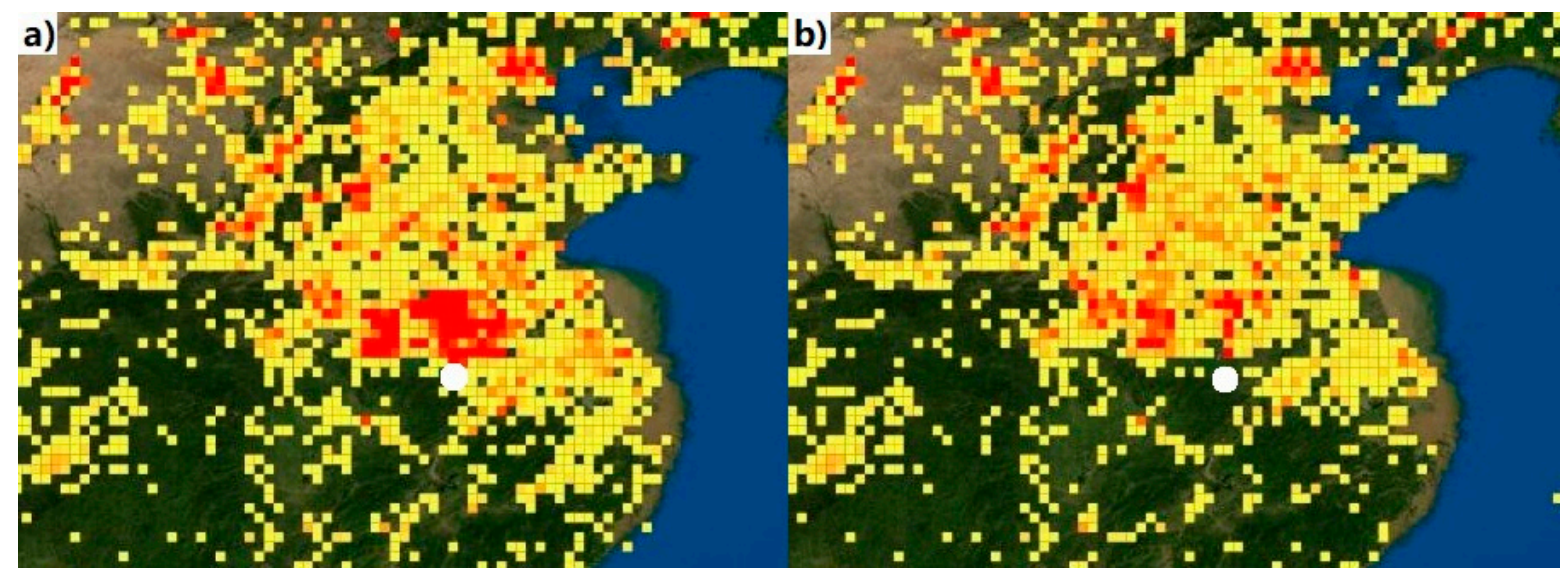

Figure 3. True color images derived from moderate resolution imaging spectroradiometry (MODIS) fires counts in June 2014 (a) and June 2015 (b). The white solid circle denotes the city of Hefei.

Monthly average aerosol optical depth (AOD) values got from the Giovanni maps of the MODIS satellite during 2014 and 2015 are exhibited in Figure 4. The mean AOD in June 2014 has a maximum value of 1.58, probably due to summertime agricultural straw combustion, as opposed to the obviously low mean value of 0.75 in June 2015. No significant correlation between PM and AOD values are observed, and the following reasons can explicate the poor association. The AOD has a bearing on extinction properties of aerosol particles. Some AOD data may not be retrieved attributed to limitations such as orbit gaps, cloud masks, and sun-glint areas. The AOD describes the aerosol columnar integral over the entire atmosphere column and is averaged over some territories, whereas the PM data are gained at a few ground-based monitoring sites, describing local aerosol properties near the surface.

The monthly variations of $\mathrm{NO}_{2}, \mathrm{SO}_{2}$, and $\mathrm{CO}$ present a U-shaped pattern with pronounced maximums appearing in December or January (Figure $2 \mathrm{c}$ and Supplementary Figure S1). Similar reasons to PM could explicate these monthly patterns which are a combined effect of enhanced pollutant discharge and relatively stable synoptic conditions in winter. Last but not least, a stronger photochemistry reaction can remove the gases quickly from the atmosphere whereas it is least active and decelerates the transformation of primary gaseous pollutants during cold months [13,37]. Compared to that in 2014, the concentrations of $\mathrm{PM}_{2.5}, \mathrm{PM}_{10}, \mathrm{SO}_{2}$, and $\mathrm{CO}$ in 2015 exhibits a marked decline in almost four seasons owing to a series of policies released by local government, while $\mathrm{NO}_{2}$ concentration in the autumn of 2015 shows the abnormal increase. $\mathrm{NO}_{2}$ emissions primarily come from traffic vehicles, power plants, and industries with energy exhaust, and vehicles account for the most $[38,39]$. The number of motor vehicles is growing quickly as an economic flourish in Hefei. Additionally, the prevailing wind direction during this period is northeast. Pollutants are easily carried to the local area with the airflow movement, resulting in high amplitudes in autumn. 


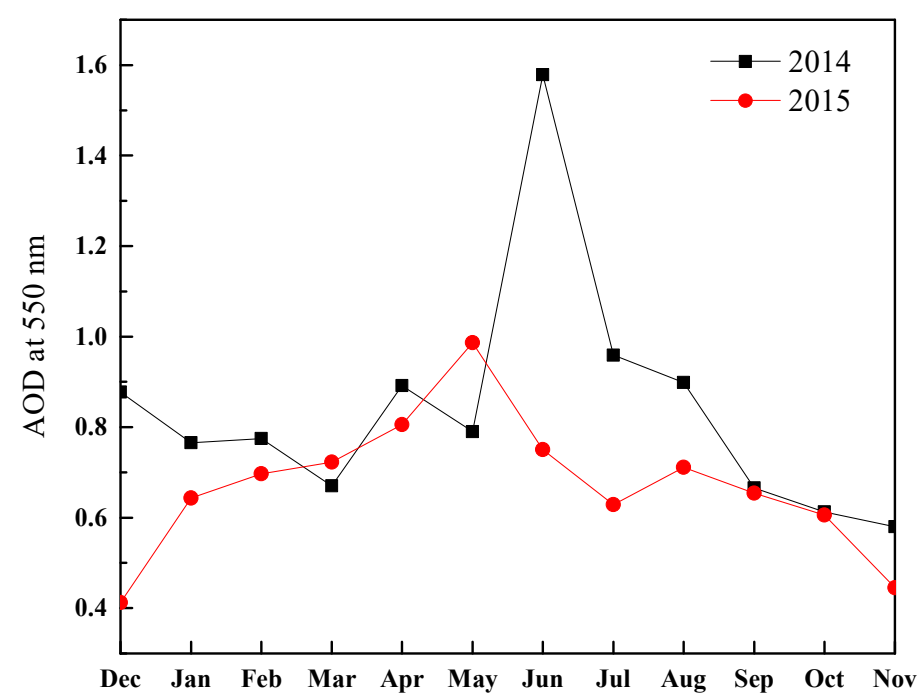

Figure 4. Monthly mean aerosol optical depth (AOD) map of area-averaged time series over urban Hefei (region: $116.5-117.5^{\circ} \mathrm{E}, 31-32^{\circ} \mathrm{N}$ ) derived from MODIS-Terra data in 2014 and 2015.

The $\mathrm{O}_{3}$ concentrations exhibit the opposite trends with inverted $\mathrm{U}$-shape (Figure 2d). Its concentration begins to increase gradually from January and demonstrates a downward trend after reaching a maximum in June $\left(79.6 \pm 22.8 \mu \mathrm{g} / \mathrm{m}^{3}\right.$ in 2014) or August $\left(96.3 \pm 18.1 \mu \mathrm{g} / \mathrm{m}^{3}\right.$ in 2015), and the minimum of the whole year is in November $\left(30.0 \pm 9.7 \mu \mathrm{g} / \mathrm{m}^{3}\right.$ in 2014) or December $\left(28.2 \pm 5.9 \mu \mathrm{g} / \mathrm{m}^{3}\right.$ in 2015). Temperature directly influences $\mathrm{O}_{3}$ production by interfering with the photochemical reaction speed and the volatile organic compounds (VOCs) emissions [40,41]. The local emissions of precursors $\left(\mathrm{NO}_{\mathrm{x}}\right.$, VOC, and $\mathrm{CO}$ ) also have an important effect on the regulation of $\mathrm{O}_{3}$ variability. Besides, $\mathrm{O}_{3}$ is also easily formed under the conditions of intense solar radiation induced by low PM concentrations [42,43]. Thus, by comparing with the $\mathrm{O}_{3}$ concentrations in 2014, the $\mathrm{O}_{3}$ in autumn and summer aggravates notably with $79.3 \%$ and $36.2 \%$ in 2015 , presumably due to the stronger $\mathrm{NO}_{2}$ emissions and/or relative mitigation of PM release.

\subsection{Diurnal Variations}

The diurnal variations of pollutants are of great significance to understand the impact of potential emission sources and meteorological parameters related to domestic cooking, traffic, and industrialization in urban regions. The concentrations of $\mathrm{PM}_{2.5}, \mathrm{PM}_{10}, \mathrm{NO}_{2}$, and $\mathrm{CO}$ generally display a flat " $\mathrm{M}$ " pattern, with two peaks and two valleys (Figure 2 and Supplementary Figure S1). The first peak occurs around approximately in the rush hours before noon (9:00-11:00) and the second peak occurs at night (20:00-24:00) aggravated by the increased inter-cities vehicular traffic from freightage that is managed and controlled in daytime, suggesting the emissions of transportation are essential to the formation and accumulation of pollutants. For the morning peak, the spring, summer and fall are earlier than winter whereas for the evening peak the winter is earlier. The peaks appear at night during winter, especially for PM, are more pronounced than other seasons which may be explained by outset of heating (i.e., coal combustion) and relative stability weather. Correspondingly, the first valley occurs in the early morning (5:00-7:00) with less anthropogenic activity and pollutant deposition. The second lower valley occurs in the late afternoon (16:00-18:00) mainly because of the relatively high low planetary boundary layer (PBL) height and other meteorological conditions, which is conducive to air pollutant dispersion.

The $\mathrm{O}_{3}$ distribution demonstrates a unimodal distribution, and its concentrations generally start to increase at 7:00 and appear as a distinct peak at afternoon approximately 15:00 (Figure 2d). As the sun sets, with the decrease of the temperature and strength of solar radiation, the $\mathrm{O}_{3}$ concentrations cut down as well, especially at night in the cold season. The discrepancy of criteria pollutants with 
exception of $\mathrm{NO}_{2}$ and $\mathrm{O}_{3}$ among four seasons is more significant during 2014. Notably, the winter varying curves of $\mathrm{PM}_{2.5}, \mathrm{PM}_{10}, \mathrm{CO}$, and $\mathrm{SO}_{2}$ are far above the curves for the other seasons during 2014 whereas the curves during spring, summer, and autumn are relatively close, indicating that winter pollution is particularly serious. Concerning the year 2015, the concentrations of $\mathrm{PM}_{2.5}, \mathrm{PM}_{10}, \mathrm{CO}$, and $\mathrm{SO}_{2}$ reduce and the seasonal curves exhibit dispersedly distribution. $\mathrm{The}^{\mathrm{NO}_{2}}$ and $\mathrm{O}_{3}$ synchronously enhance during 2015 reflecting local anthropogenic emissions or regional transportation effects.

To better understand the contribution of various components to ambient pollution, the proportions of major pollutants, defined as the pollutant with the largest AQI when AQI > 100 are presented in Figure 5. On the annual basis, $\mathrm{PM}_{2.5}$ is the dominant major pollutant and occupies about half of 2014 and a quarter of 2015. $\mathrm{PM}_{10}$ occasionally acts as the major pollutants on a small number of days with only 6-7 days. Astoundingly, no gas species are found as major pollutants during the studied period. A non-attainment day refers to the day with any pollutant concentration outstripping CAAQS grade II of concentration limits for $24 \mathrm{~h}$ average (AQI $>100$ ). Hefei suffers severe air pollution with 178 days of exceedance during 2014, and the polluted proportion totals $49 \%$. For 2015, air quality gets better with 91 days of exceedance and the substandard ratio of about $25 \%$. A comprehensive analysis of the air quality evaluation on a seasonal basis is also made, and the non-attainment percentage is in the order of Winter (2014: 78\%; 2015: 50\%) > Spring (2014: 44\%; 2015: 24\%) > Autumn (2014: 42\%; 2015: 23\%) > Summer (2014: $33 \% ; 2015: 4 \%$ ). In contrary to trivial gas pollution, $\mathrm{PM}$, especially $\mathrm{PM}_{2.5}$, is the main factor causing air pollution in Hefei.

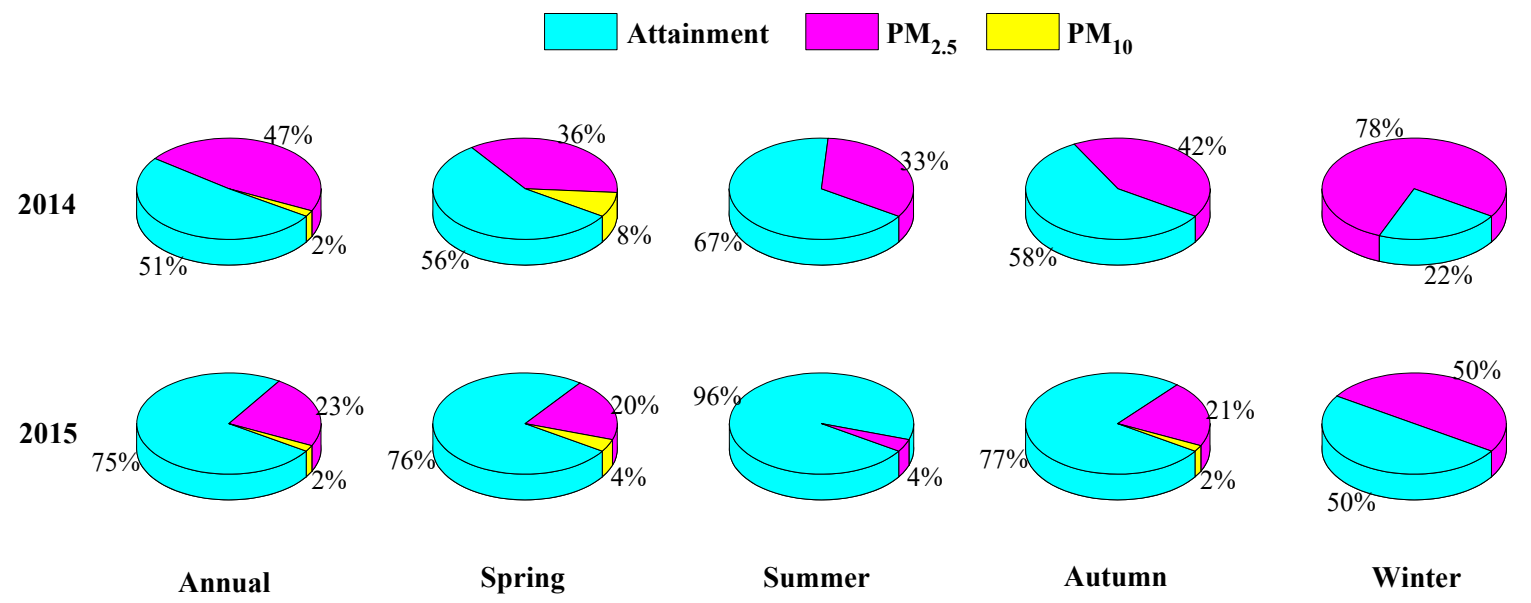

Figure 5. The fractions of major pollutants during 2014 and 2015.

\subsection{Spatial Distribution}

The detailed average ambient pollutant concentrations at different sampling sites during 2015 are summarized in Table 3. The highest mean daily PM concentrations are observed at YR and LY. Meanwhile, $\mathrm{PP}$ and DP have the highest $\mathrm{O}_{3}$ levels, SL has the highest $\mathrm{NO}_{2}$ concentration, and $\mathrm{SO}_{2}$ and $\mathrm{CO}$ concentrations at ten sites are similar. The different monitoring sites exhibit obvious spatial differences related much to their emission sources. $\mathrm{PM}_{2.5}$ congruously exceeds the CAAQS grade II more frequently than the other pollutants, implying air pollution in this region is primarily caused by a high level of $\mathrm{PM}_{2.5}$.

Generally, the sites clustered in old districts (YR, YH, SL, and AV) have the highest pollution levels, followed by urban periphery sites (LY, DP, BH, and PP), while new districts (HT and BN) have the cleanest air. The reasons for this phenomenon include the greater artificial release of PM caused by the larger population density and more frequent human activities such as vehicles and catering. Furthermore, the southern part of Hefei (BN, BH, PP, and HT) is located very close the lake district of Lake Chaohu, where the air is relatively moist and anthropogenic emissions are relatively small. 
On the contrary, the northern part of Hefei is near coal cities such as Huainan. As a result, the PM concentrations in the north sites are higher than those in the south.

Table 3. Average diurnal concentrations of six criteria air pollutants at ten stations in Hefei during 2015 (units are $\mu \mathrm{g} / \mathrm{m}^{3}$ for $\mathrm{PM}_{2.5}, \mathrm{PM}_{10}, \mathrm{SO}_{2}, \mathrm{NO}_{2}$, and $\mathrm{O}_{3}$, and $\mathrm{mg} / \mathrm{m}^{3}$ for $\mathrm{CO}$ ).

\begin{tabular}{cccccccc}
\hline Station & Description & $\mathbf{P M}_{\mathbf{2 . 5}}$ & $\mathbf{P M}_{\mathbf{1 0}}$ & $\mathbf{S O}_{\mathbf{2}}$ & $\mathbf{N O}_{\mathbf{2}}$ & $\mathbf{C O}$ & $\mathbf{O}_{\mathbf{3}}$ \\
\hline old district & & & & & & & \\
YR & Yangtze River Road & 64.6 & 106.6 & 21.0 & 35.6 & 1.2 & 71.8 \\
YH & Yaohai District & 66.3 & 99.1 & 13.7 & 31.2 & 1.1 & 77.0 \\
SL & Sanlijie & 61.8 & 96.7 & 14.1 & 58.4 & 1.1 & 94.7 \\
AV & Amber Villa & 64.9 & 90.9 & 18.1 & 26.2 & 0.9 & 79.9 \\
\hline urban periphery & & & & & & & \\
LY & Luyang District & 65.9 & 99.3 & 18.4 & 15.3 & 1.0 & 40.9 \\
DP & Dongpu Reservoir & 60.5 & 90.9 & 20.0 & 26.9 & 0.7 & 92.6 \\
BH & Baohe District & 57.5 & 88.7 & 18.8 & 26.3 & 1.0 & 52.3 \\
PP & Pearl Plaza & 56.9 & 88.9 & 20.3 & 55.8 & 1.0 & 102.2 \\
\hline new district & & & & & & & \\
HT & High-tech Zone & 60.8 & 87.7 & 16.6 & 17.5 & 1.0 & 38.1 \\
BN & Binhu New Zone & 58.9 & 90.6 & 11.0 & 19.3 & 0.9 & 39.4 \\
\hline
\end{tabular}

In addition to the high concentration of PM in the old districts, serious pollution is also observed at LY on the urban periphery. The government supports and encourages the development of Luyang Industrial Park, focusing on the boom of modern printing, heat and power equipment, building materials, as well as agricultural by-products processing industries. Both distinct urban air pollution and straw burning in nearby suburb affect air quality in LY. PM pollution is alleviated at DP, the background site of Hefei. Botanical Garden is located to the east of DP site, and DP is surrounded by reservoirs using for flood control with no nearby emission sources, possessing favorable topographical conditions for atmospheric dispersion. Higher $\mathrm{O}_{3}$ concentrations occur at DP, attributed to biogenic VOC emissions. Additionally, the seasonal variation tendency of pollutant concentrations at ten sites shows high consistency (no shown), implying the regional characteristic of six pollutants in the atmosphere at Hefei to some extent.

\subsection{Air Pollutants on Episode and Non-Episode Days}

$\mathrm{PM}_{2.5}$ pollution in Hefei is serious with about $49 \%$ and $25 \%$ of the daily concentrations exceed the diurnal limit during 2014 and 2015, respectively. Herein, the days are classified into episode days $\left(\mathrm{PM}_{2.5}>75 \mu \mathrm{g} / \mathrm{m}^{3}\right)$ and non-episode days. The $\mathrm{PM}_{2.5} / \mathrm{PM}_{10}$ ratio and $\mathrm{PM}_{2.5} / \mathrm{CO}$ ratio are calculated to characterize the PM pollution further. These ratios can not only provide insights into characteristics of particle pollution but also have been used to reveal the sources of PM $[35,44]$. Both $\mathrm{PM}_{2.5} / \mathrm{PM}_{10}$ ratios and $\mathrm{PM}_{2.5} / \mathrm{CO}$ ratios on episode days $\left(\mathrm{PM}_{2.5} / \mathrm{PM}_{10}\right.$ : 0.74 for 2014 and 2015; $\mathrm{PM}_{2.5} / \mathrm{CO}: 0.095$ for 2014 and 0.084 for 2015 , respectively) are obviously higher than that on non-episode days $\left(\mathrm{PM}_{2.5} / \mathrm{PM}_{10}: 0.62\right.$ for 2014 and 0.61 for 2015; $\mathrm{PM}_{2.5} / \mathrm{CO}: 0.062$ for 2014 and 0.052 for 2015, respectively). The interspecies relationship between the $\mathrm{PM}_{2.5}$ and $\mathrm{PM}_{10}$ is also examined in terms of Pearson correlations $(\mathrm{R})$ analysis (Table 4), and the results exhibit that the value is 0.81 during episode days, significantly higher than that in non-episode period (0.68), further demonstrating $\mathrm{PM}_{2.5}$ accounts for large fractions of $\mathrm{PM}_{10}$ and the differences between the two sources are small in episode pollution period. The CO is a key molecular marker of the intensity of anthropogenic burning [45-47]. Diurnal CO concentrations are $1.41 \mathrm{mg} / \mathrm{m}^{3}$ and $1.33 \mathrm{mg} / \mathrm{m}^{3}$ during the episode days of 2014 and 2015, obviously higher than those of the non-episode days $\left(0.81 \mathrm{mg} / \mathrm{m}^{3}\right.$ for 2014 and $0.89 \mathrm{mg} / \mathrm{m}^{3}$ for 2015) as well. Simultaneously, more remarkable positive correlations are found between $\mathrm{PM}_{2.5}$ and $\mathrm{CO}$ for episode days (0.82 for episode days and 0.57 for non-episode days), implying that $\mathrm{CO}$ emission process is accompanied by the emission of $\mathrm{PM}_{2.5}$. Moreover, stronger correlations are found between $\mathrm{PM}_{2.5}$ and $\mathrm{NO}_{2} / \mathrm{SO}_{2}$ 
for episode days (Table 4). High ratios in $\mathrm{PM}_{2.5} / \mathrm{PM}_{10}$ and $\mathrm{PM}_{2.5} / \mathrm{CO}$ during haze episode days are attributed to the formation of secondary aerosols by the oxidation of gaseous pollutants $\left(\mathrm{SO}_{2}, \mathrm{NO}_{2}\right.$, and $\mathrm{CO}$ ). The fluctuations for seasonal variations of $\mathrm{PM}_{2.5} / \mathrm{PM}_{10}$ and $\mathrm{PM}_{2.5} / \mathrm{CO}$ are mainly related to anthropogenic sources and atmospheric conditions (Supplementary Figure S2).

Table 4. The Pearson Correlations between six pollutants and meteorological elements (RH: relative humidity; T: temperature; WS: wind speed) in the non-episode days (cells above the diagonal) and episode days (cells below the diagonal).

\begin{tabular}{cccccccccc}
\hline & $\mathbf{R H}$ & $\mathbf{T}$ & $\mathbf{W S}$ & $\mathbf{P M}_{\mathbf{2 . 5}}$ & $\mathbf{P M}_{\mathbf{1 0}}$ & $\mathbf{S O}_{\mathbf{2}}$ & $\mathbf{C O}$ & $\mathbf{N O}_{\mathbf{2}}$ & $\mathbf{O}_{\mathbf{3}}$ \\
\hline $\mathbf{R H}$ & - & 0.13 & -0.09 & -0.18 & -0.53 & -0.47 & 0.10 & -0.31 & -0.18 \\
$\mathbf{T}$ & 0.16 & - & -0.08 & -0.20 & 0.12 & -0.57 & 0.02 & -0.06 & 0.58 \\
$\mathbf{W S}$ & -0.18 & 0.00 & - & -0.29 & -0.25 & -0.02 & -0.38 & -0.36 & -0.13 \\
$\mathbf{P M}_{2.5}$ & -0.06 & -0.29 & -0.08 & - & 0.68 & 0.43 & 0.57 & 0.36 & 0.02 \\
$\mathbf{P M}_{\mathbf{1 0}}$ & -0.16 & 0.02 & -0.15 & 0.81 & - & 0.39 & 0.40 & 0.48 & 0.24 \\
$\mathbf{S O}_{\mathbf{2}}$ & -0.43 & -0.51 & -0.06 & 0.52 & 0.45 & - & 0.25 & 0.31 & -0.33 \\
$\mathbf{C O}$ & 0.15 & -0.27 & -0.26 & 0.82 & 0.67 & 0.48 & - & 0.57 & 0.12 \\
$\mathbf{N O}_{\mathbf{2}}$ & -0.28 & -0.28 & -0.40 & 0.36 & 0.44 & 0.50 & 0.54 & - & 0.28 \\
$\mathbf{O}_{\mathbf{3}}$ & -0.09 & 0.68 & -0.03 & -0.14 & 0.10 & -0.29 & -0.17 & -0.02 & - \\
\hline
\end{tabular}

Besides the direct primary emissions and secondary formation of PM, the meteorological conditions during episode days in Hefei are also playing an important effect on accelerating the aggregation of $\mathrm{PM}_{2.5}$ (Tables 2 and 4). A negative relationship is found between temperature and PM and gaseous pollutants except $\mathrm{O}_{3}$. Based on the analysis of the temperature pattern, the episode days occur more often during the lowest temperature. For example, the highest frequency of episode days is up to $53 \%$ with $\mathrm{T}<7{ }^{\circ} \mathrm{C}$, whereas the corresponding data is about $28 \%$ as $\mathrm{T}>25^{\circ} \mathrm{C}$ during the entire period. Relative humidity, accumulated rainfall, and wind speed are higher in non-episode days, and all exhibit more strongly reverse correlation with PM as compared to that in episode days.

\subsection{Pollutants Source Analysis Based on HYSPLIT, PSCF, and CWT}

To assess local emission and regional transport of pollutants on air quality, the $72 \mathrm{~h}$ back trajectories from the central location of Hefei are clustered during $\mathrm{PM}_{2.5}$ episode days (Figure 6). PSCF and CWT models are conducted to make further efforts to reveal the potential source-areas and their relative contribution to the receptor site (Figures 7 and 8). The topographical feature of Hefei signifies that it is easily affected by the polluted atmosphere that originated from its adjacent regions.

During springtime, the wind rose demonstrates that the prevailing wind is from the east (northeast, east, and southeast) (Supplementary Figure S3 and Supplementary Figure S4). The pollutants mainly come from local emissions (Cluster 2: $52 \%$ ) and shorter-distance transport from YRD to the east (Cluster 1: 42\%) region. Additionally, the frequency of dust weather in most parts of northern China is relatively high in spring, and air masses from these places carry the aerosol particles to Hefei and make the pollution in this area worse (Cluster 3: 6\%). As displayed in Figures 7 and 8, high PSCF/CWT to $\mathrm{PM}_{2.5}$ concentrations for Hefei is observed in south regions of Anhui and Jiangsu, southwest of Zhejiang, and northeast of Jiangxi with a PSCF $>0.5$ and CWT $>75 \mu \mathrm{g} / \mathrm{m}^{3}$.

Summer is the best time of year for air quality, with mean $\mathrm{PM}_{2.5}$ concentrations of $69 \mu \mathrm{g} / \mathrm{m}^{3}$ $\left(41 \mu \mathrm{g} / \mathrm{m}^{3}\right)$ and attainment percentage of $67 \%$ (96\%) during 2014 (2015). During summer, for one thing, PM emissions and secondary aerosol precursors are weak; for another, air masses are primarily derived from relatively clean regions under prevailing east wind (Supplementary Figures S3 and S4). Especially, air masses originating from the sea carry abundant water vapor and are beneficial to the formation of summer rainfall, and the accumulation of seasonal concentration of pollutants like $\mathrm{PM}_{2.5}$ is difficult during this period. Two clusters are identified during summer episode days. Cluster 1-Northest, accounting for $33 \%$ of air masses, stems from Bohai Bay and travels across middle of Shandong and North Jiangsu Province before reaching Hefei. Cluster 2-East is derived from Shanghai, across North 
Zhejiang and South Jiangsu Province before arriving at Hefei, accounting for $67 \%$ of total trajectories. The East Sea, north of Shandong Peninsula, and southwest of Jiangsu are identified as major potential sources areas of ambient $\mathrm{PM}_{2.5}$ by PSCF/CWT models. Furthermore, as compared to other seasons, both PSCF and CWT values are obviously lower in summer.

During autumn-time, major trajectories are divided into three groups by clusters analysis, accounting for 37\% (Cluster 1), 59\% (Cluster 2), and 5\% (Cluster 3) of the total trajectories, respectively. Cluster 1 originates from the North China Plain (NCP). Cluster 2 begins in the YRD region, accounting for the largest percentage with features of short-distance air transport. Cluster 3 starts from Xinjiang, and passes through Inner Mongolia, Shanxi, Henan Province, and then reaches Hefei, which clearly indicates an extremely longer transport pathway in autumn. PSCF/CWT models identify that the south of Anhui and Jiangsu, north of Zhejiang, and northwest of Shandong are major potential sources areas of $\mathrm{PM}_{2.5}$.

Greater artificial release of $\mathrm{PM}_{2.5}$ is found in wintertime, and its average concentration is $141.2 \mathrm{ug} / \mathrm{m}^{3}\left(85 \mathrm{ug} / \mathrm{m}^{3}\right)$, with only 22\% (50\%) attainment in 2014 (2015). A northwest pollution source with long-distance transmission is also observed for winter, but it is larger than that for autumn with accounting for approximately $27 \%$ of air masses. Local emissions from industry and fossil fuel and short-distance transmission from serious polluted NCP and YRD regions are the primary cause of the high levels of $\mathrm{PM}_{2.5}$, accounting for 39\% and 34\%, respectively. As illustrated in Figures 7 and 8, the contribution from local emissions is found to be more striking for winter than the other three seasons, covering all the cities in Anhui Province. Particularly, high PSCF/CWT peaks, located in the south of Jiangsu and northwest of Shandong in autumn, spread to the whole Jiangsu and Shandong and most areas of Jiangxi, Henan, and Hubei Province, revealing that cross-boundary transport is crucial to $\mathrm{PM}_{2.5}$ pollution. Hefei also has a weak contribution to $\mathrm{PM}_{2.5}$ from distant Inner Mongolia and Xinjiang to the north with PSCF values basically between 0.2 and 0.5 and CWT between 25 and $75 \mu \mathrm{g} / \mathrm{m}^{3}$. Particularly, the East China Sea, the Yellow Sea, and the adjacent coastal region are potential sources of $\mathrm{PM}_{2.5}$.
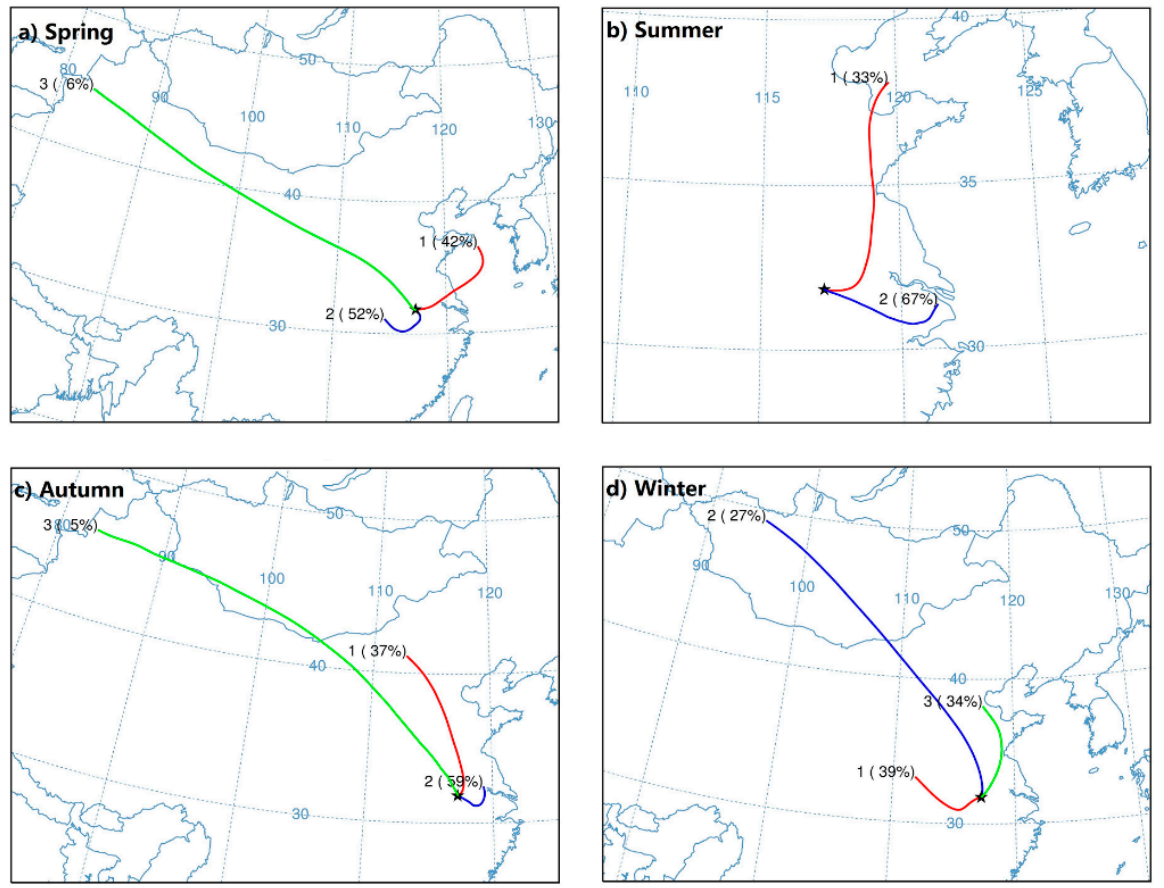

Figure 6. $72 \mathrm{~h}$ airmass backward trajectories analysis during episode days $\left(\mathrm{PM}_{2.5}>75 \mu \mathrm{g} / \mathrm{m}^{3}\right)$ from December 2013 to November 2015. 

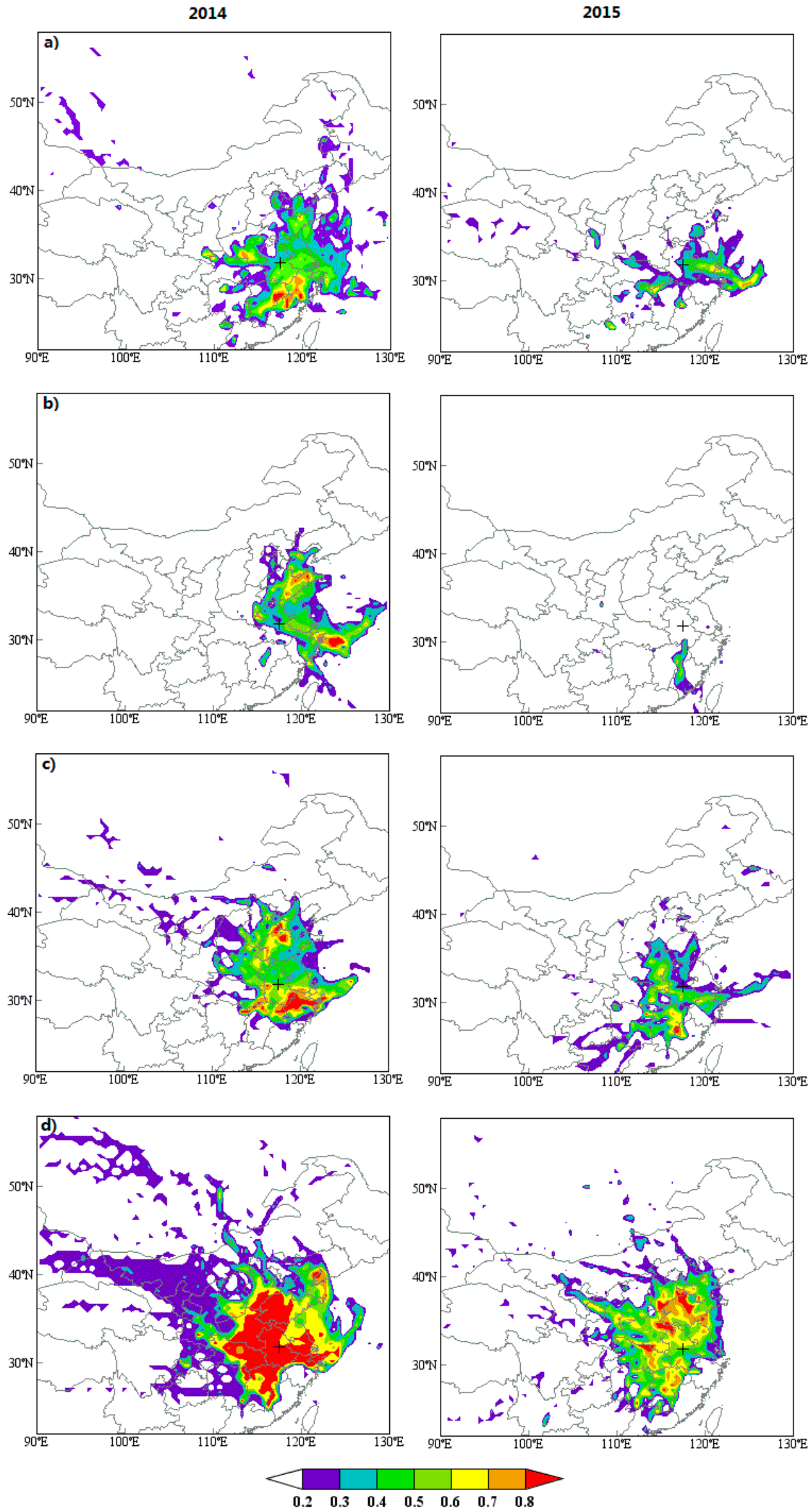

Figure 7. Seasonal potential source contribution function (PSCF) maps for $\mathrm{PM}_{2.5}$ at Hefei in 2014 and 2015: (a) spring, (b) summer, (c) autumn, (d) winter. The center of Hefei is marked by the cross and the PSCF values are displayed in color. 

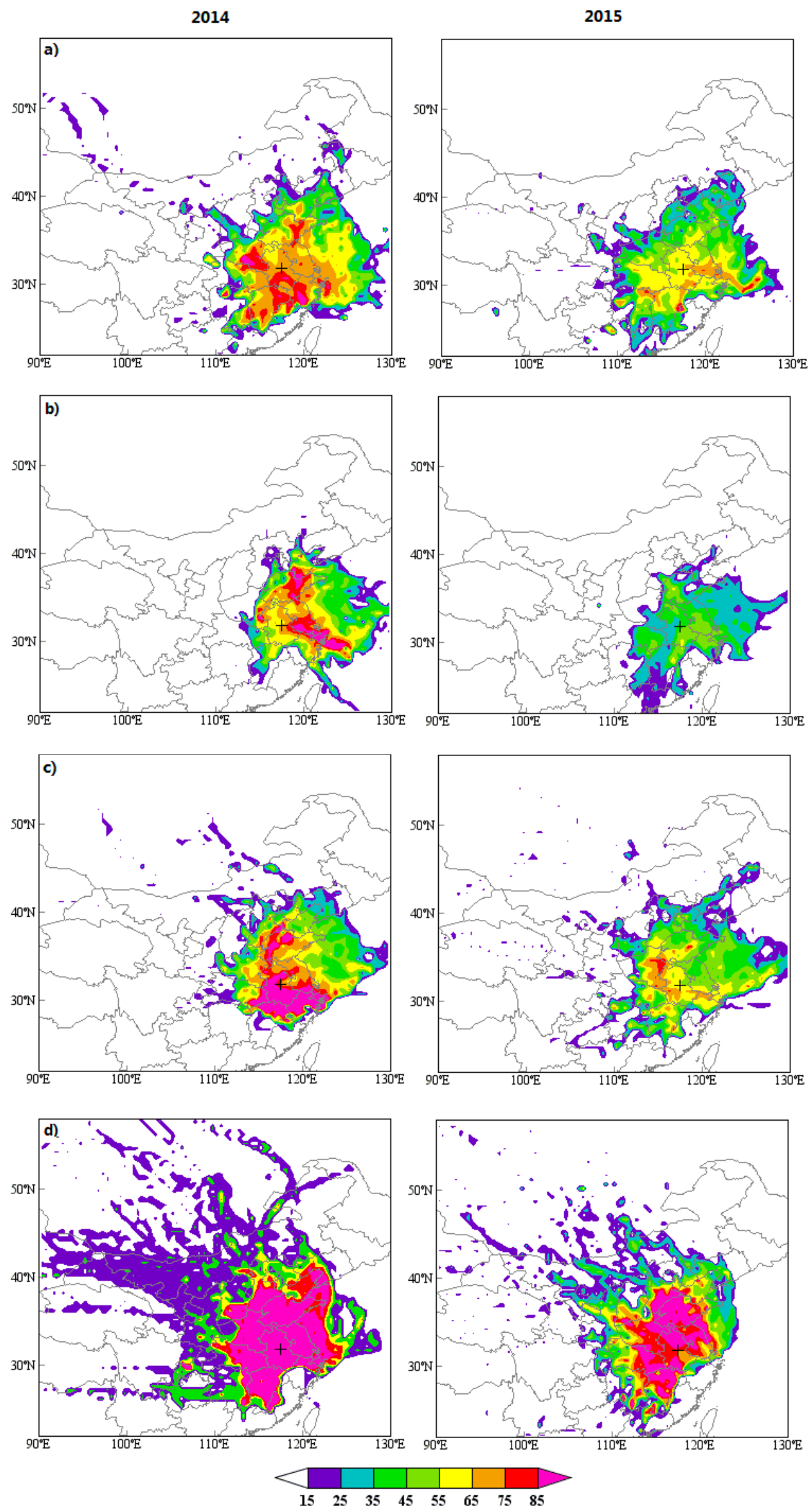

Figure 8. Seasonal concentration-weighted trajectory (CWT) maps for $\mathrm{PM}_{2.5}$ at Hefei in 2014 and 2015: (a) spring, (b) summer, (c) autumn, (d) winter. The center of Hefei is marked by the cross and the CWT values are displayed in color. 
In brief, the potential sources explicate obvious seasonal variation characteristics, and joint pollution control and prevention measurements need to further improve and implement on clean air in Hefei due to the impact of cross-boundary transportation.

\subsection{Health Burdens Attributed to $P M_{2.5}$ Exposure}

Considering that $\mathrm{PM}_{2.5}$ is the trigger of some disease, the IER function, developed for the Global Burden of Disease Study, is used to produce a reasonable prediction of the relative risks of different diseases. The attributable fractions (AFs) of the $\Delta$ Mort attributable to $\mathrm{PM}_{2.5}$ exposure in Hefei are $48 \%$ $(44 \%), 32 \%(29 \%), 32 \%(26 \%)$, and 25\% (21\%) for STR, IHD, LC, and COPD in 2014 (2015), respectively (Supplementary Table S1). Similar to previous studies, a particularly strong correlation is revealed between excess STR mortality and $\mathrm{PM}_{2.5}$ exposure [48-51]. With reducing $\mathrm{PM}_{2.5}$ concentrations, the avoidable $\Delta$ Mort caused by different diseases decreases correspondingly (Figure 9 ). The $\Delta$ Mort reduction rate caused by LC and COPD is higher than STR and IHD, suggesting the benefits of reducing $\mathrm{PM}_{2.5}$ for respiratory diseases are higher than those for cardiovascular disease. Regardless of population growth in 2014 , a $60 \%$ reduction of $\mathrm{PM}_{2.5}$ will result in $27 \%, 27 \%, 44 \%$, and $43 \% \Delta$ Mort reductions for STR, IHD, LC, and COPD, respectively. The corresponding $\triangle$ Mort reductions are $44 \%$, $30 \%, 47 \%$, and $48 \%$ relative to the 2015 level. $\mathrm{PM}_{2.5}$ concentrations need to be reduced by $63 \%, 80 \%$, $65 \%$, and $65 \%$ from the 2014 level to achieve a 50\% reduction in STR, IHD, LC, and COPD-caused $\Delta$ Morts, and $63 \% 75 \%, 62 \%$, and $60 \%$ relative to the 2015 level, respectively. A total of $50 \% \Delta$ Mort reduction requires an average of $72 \%(65 \%)$ reduction of $\mathrm{PM}_{2.5}$ in 2014 (2015), respectively.

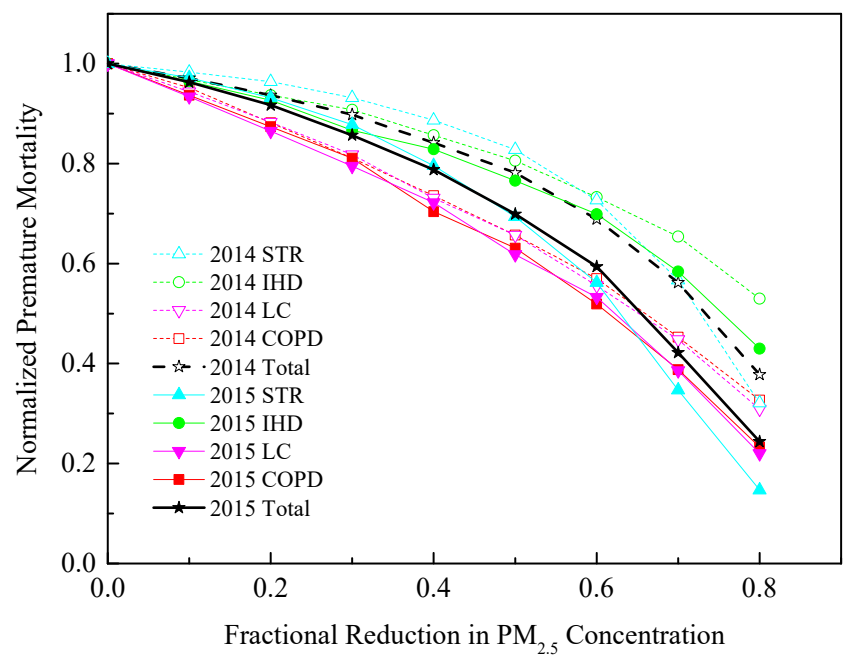

Figure 9. The avoidable premature mortality by cutting down $\mathrm{PM}_{2.5}$ concentrations to different levels.

The potential avoidable $\Delta$ Mort in Hefei due to $\mathrm{PM}_{2.5}$ exposure will be reduced by $32 \%$ from 9.44 to 6.44 thousand mortalities for situations in which ambient $\mathrm{PM}_{2.5}$ concentrations in 2014 meet the current CAAQS grade II standard. The evaluated avoidable death percentage will be $47 \%, 70 \%$, and $85 \%$ when further reducing the $\mathrm{PM}_{2.5}$ concentrations to $25 \mu \mathrm{g} / \mathrm{m}^{3}$ (WHO IT2), $15 \mu \mathrm{g} / \mathrm{m}^{3}$ (WHO IT3), and $10 \mu \mathrm{g} / \mathrm{m}^{3}$ (WHO AQG), respectively (Figure 10). In 2015, the total $\Delta$ Mort is about 8.53 thousand, and the mortality benefits will be $24 \%, 41 \%, 67 \%$, and $83 \%$ of the excess mortalities attributable to $\mathrm{PM}_{2.5}$ if the $\mathrm{PM}_{2.5}$ concentrations are to meet the aforementioned four levels, respectively. The health burdens associated with $\mathrm{PM}_{2.5}$ in Hefei are still rigorous, much higher health benefits could be achieved if adopting more stringent WHO guidelines such as WHO IT3. 


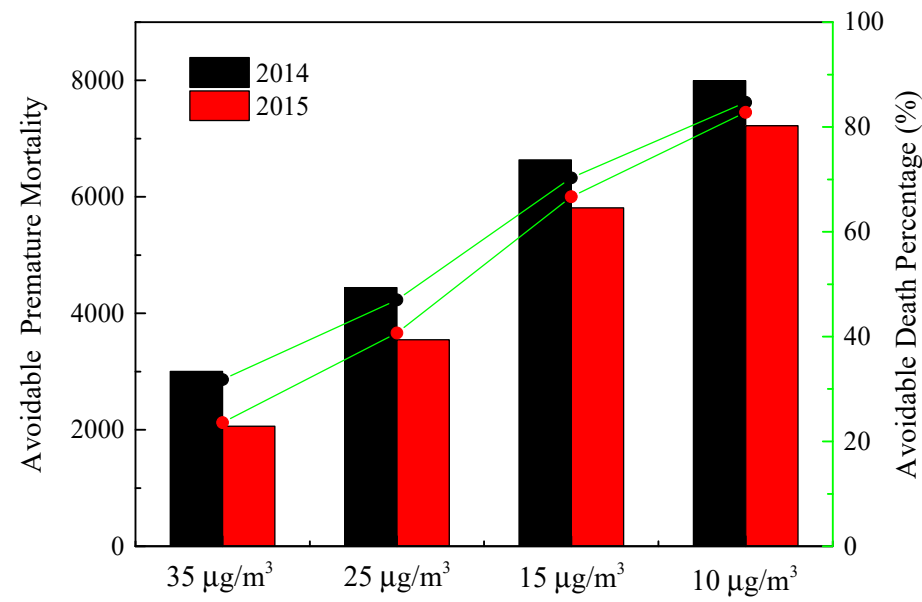

Figure 10. Potentially avoidable premature mortality and associated percentage from cutting down $\mathrm{PM}_{2.5}$ concentrations to four standards.

\section{Conclusions}

In this study, recently released air quality data with high spatial-temporal resolution are used to investigate the air pollution characteristics, influence factor, and associated health burden in the city of Hefei, central China. The annual $\mathrm{PM}_{2.5}\left(\mathrm{PM}_{10}\right)$ concentrations during 2014 and 2015 are $89.1 \pm 59.4 \mu \mathrm{g} / \mathrm{m}^{3}\left(118.9 \pm 66.8 \mu \mathrm{g} / \mathrm{m}^{3}\right)$ and $61.6 \pm 32.2 \mu \mathrm{g} / \mathrm{m}^{3}\left(91.3 \pm 40.9 \mu \mathrm{g} / \mathrm{m}^{3}\right)$, respectively, which exceed the CAAQS II standards. By comparison, trace gases $\left(\mathrm{NO}_{2}, \mathrm{CO}, \mathrm{SO}_{2}\right.$, and $\left.\mathrm{O}_{3}\right)$ concentrations are consistently below Grade-II limit. The Monthly (diurnal) variations of the pollutants with the exception of $\mathrm{O}_{3}$ present " $\mathrm{U}$ " (flat " $\mathrm{M}$ ") shape, whereas the $\mathrm{O}_{3}$ appears completely adverse trend pattern. The highest $\mathrm{PM}_{2.5}$ concentrations occur in cold seasons (January and December) as a result of synchronous control by emission from additional local heating and meteorological factors. $\mathrm{PM}_{2.5}$ is the major factor causing air pollution, and no gas species are found as major pollutants. Among 10 sites in Hefei, sites clustered in old districts have the highest pollution levels, followed by urban periphery sites, while new districts have the cleanest air. Higher ratios between $\mathrm{PM}_{2.5}$ and $\mathrm{PM}_{10}$ and $\mathrm{CO}$ for haze episode days than that for non-episode days reveal that the formation of secondary aerosols aggravates air pollution. According to the results of backward trajectory calculations, the ambient pollutant concentrations in Hefei tend to be influenced not only by air masses originated locally but also by air masses with short-distance and long-distance regional transport from adjacent provinces (especially Jiangsu, Hebei, Zhejiang, and Shandong) and remote region (Mongolia and Xinjiang), respectively. Based on the PSCF/CWT analysis, the potential sources explicate distinct seasonal variations. The common high-potential source regions of $\mathrm{PM}_{2.5}$ are located in most areas of Anhui, southern Jiangsu, northern Zhejiang, and western Shandong since these areas are the most important industrial base in China with dense population, rising energy consumption, as well as affected by higher pollutant emissions. Supposing that the $\mathrm{PM}_{2.5}$ concentrations are to meet the CAAQS grade II, the WHO IT-2, IT-3, and AQG, it will be possible to achieve mortality benefits of $32 \%, 47 \%, 70 \%$, and $85 \%$ of the total premature mortalities (9.44 thousand) in 2014 , and $24 \%, 41 \%, 67 \%$, and $83 \%$ of the total premature mortalities (8.53 thousand) in 2015, respectively. This work suggests that cross-regional control measures and adopting more stringent standards are crucial to improve air quality in the region of urban central China.

Supplementary Materials: The following are available online at http://www.mdpi.com/1660-4601/17/1/229/s1: Data and Methods, Figure S1: Diurnal variations of $\mathrm{SO}_{2}$ (upper) and $\mathrm{CO}$ (down), Figure S2: The seasonal variations of $\mathrm{PM}_{2.5} / \mathrm{PM}_{10}$ ratios and $\mathrm{PM}_{2.5} / \mathrm{CO}$ ratios, Figure S3: The relationship between percent frequency and wind speed, direction for seasonal distribution in 2014 at Hefei, Figure S4: The relationship between percent frequency and wind speed, direction for seasonal distribution in 2015 at Hefei, Table S1: The attributable fractions due to $\mathrm{PM}_{2.5}$ for STR, IHD, LC, and COPD. 
Author Contributions: M.M. conceived the study and wrote the manuscript; Y.S. collected the data; X.Z. and Y.Y. supervised and contributed to the revision. All authors have read and agreed to the published version of the manuscript.

Funding: This work was funded by the National Natural Science Foundation of China (Nos. 91644224, 41505127).

Acknowledgments: Key Lab of Photovoltaic and Energy Conservation Materials (PECL2019KF006), the Chinese Academy of Sciences, is gratefully acknowledged by the authors.

Conflicts of Interest: The authors declare no conflict of interest.

\section{References}

1. He, K.; Huo, H.; Zhang, Q. Urban air pollution in China: Current status, characteristics, and process. Annu. Rev. Energy Environ. 2002, 27,397-431. [CrossRef]

2. Ma, X.; Jia, H.; Sha, T.; An, J.; Tian, R. Spatial and seasonal characteristics of particulate matter and gaseous pollution in China: Implications for control policy. Environ. Pollut. 2019, 248, 421-428. [CrossRef]

3. Guilloteau, A.; Bedjanian, Y.; Nguyen, M.L.; Tomas, A. Desorption of polycyclic aromatic hydrocarbons from a soot surface: Three- to five-ring PAHs. J. Phys. Chem. A 2009, 114, 942-948. [CrossRef] [PubMed]

4. Barrado, A.I.; Garcia, S.; Sevillano, M.L.; Rodriguez, J.A.; Barrado, E. Vaporphase concentrations of PAHs and their derivatives determined in a large city: Correlations with their atmospheric aerosol concentrations. Chemosphere 2013, 93, 1678-1684. [CrossRef]

5. Pope, A.C.; Dockery, D.W. Critical review: Health effects of fine particulate air pollution: Lines that connect. J. Air Waste Manag. Assoc. 2006, 56, 709-742. [CrossRef] [PubMed]

6. Chen, H.; Lin, Y.; Su, Q.; Chen, L. Spatial variation of multiple air pollutants and their potential contributions to all-cause, respiratory, and cardiovascular mortality across China in 2015-2016. Atmos. Environ. 2017, 168, 23-35. [CrossRef]

7. Lelieveld, J.; Evans, J.S.; Fnais, M.; Giannadaki, D.; Pozzer, A. The contribution of outdoor air pollution sources to premature mortality on a global scale. Nature 2015, 525, 367-371. [CrossRef]

8. Wang, S.X.; Hao, J.M. Air quality management in China: Issues, challenges, and options. J. Environ. Sci. 2012, 24, 2-13. [CrossRef]

9. Ministry of Environment Protection of China (MEP). Ambient Air Quality Standards; GB 3095-2012; China Environmental Science Press: Beijing, China, 2012; p. 12. (In Chinese)

10. Guan, Q.Y.; Cai, A.; Wang, F.F.; Yang, L.Q.; Xu, C.Q.; Liu, Z.Y. Spatio-temporal variability of particulate matter in the key part of Gansu Province, Western China. Environ. Pollut. 2017, 230, 189-198. [CrossRef]

11. Sun, Y.L.; Wang, Z.F.; Fu, P.Q.; Yang, T.; Jiang, Q.; Dong, H.B.; Li, J.; Jia, J.J. Aerosol composition, sources and processes during wintertime in Beijing, China. Atmos. Chem. Phys. 2013, 13, 4577-4592. [CrossRef]

12. Miao, Y.; Guo, J.; Liu, S.; Liu, H.; Li, Z.; Zhang, W.; Zhai, P. Classification of summertime synoptic patterns in Beijing and their associations with boundary layer structure affecting aerosol pollution. Atmos. Chem. Phys. 2017, 17, 3097-3110. [CrossRef]

13. Zhang, G.; Xu, H.; Qi, B.; Du, R.; Gui, K.; Wang, H.; Jiang, W.; Liang, L.; Xu, W. Characterization of atmospheric trace gases and particulate matter in Hangzhou. China. Atmos. Chem. Phys. 2018, 18, 1705-1728. [CrossRef]

14. Ma, X.; Jia, H. Particulate matter and gaseous pollution in three megacities over China: Situation and implication. Atmos. Environ. 2016, 140, 476-494. [CrossRef]

15. Wang, L.; Xiong, Q.; Wu, G.; Gautam, A.; Jiang, J.; Liu, S.; Zhao, W.; Guan, H. Spatio-temporal variation characteristics of $\mathrm{PM}_{2.5}$ in the Beijing-Tianjin-Hebei Region, China, from 2013 to 2018. Int. J. Environ. Res. Public Health 2019, 16, 4276. [CrossRef]

16. Chen, T.; He, J.; Lu, X.; She, J.; Guan, Z. Spatial and temporal variations of $\mathrm{PM}_{2.5}$ and its relation to meteorological factors in the urban area of Nanjing, China. Int. J. Environ. Res. Public Health 2016, 13, 921. [CrossRef]

17. Mao, M.; Zhang, X.; Yin, Y. Particulate matter and gaseous pollutions in three metropolises along the Chinese Yangtze River: Situation and Implications. Int. J. Environ. Res. Public Health 2018, 15, 1102. [CrossRef]

18. Huang, L.; Chen, M.; Hu, J. Twelve-year trends of $\mathrm{PM}_{10}$ and visibility in the Hefei metropolitan area of China. Adv. Meteorol. 2016, 2016, 4810796. [CrossRef] 
19. Zhang, X.L.; Mao, M. Brown haze types due to aerosol pollution at Hefei in the summer and fall. Chemosphere 2015, 119, 1153-1162. [CrossRef]

20. Zhang, X.L.; Mao, M.; Yin, Y. Optically effective complex refractive index of coated black carbon aerosols: From numerical aspects. Atmos. Chem. Phys. 2019, 19, 7507-7518. [CrossRef]

21. Zhang, X.L.; Rao, R.Z.; Huang, Y.B.; Mao, M.; Berg, M.J.; Sun, W.B. Black carbon aerosols in urban central China. J. Quant. Spectrosc. Radiat. Transf. 2015, 150, 3-11. [CrossRef]

22. Hong, Q.; Xie, Z.; Liu, C.; Wang, F.; Xie, P.; Kang, H.; Xu, J.; Wang, J.; Wu, F.; He, P.; et al. Speciated atmospheric mercury on haze and non-haze days in an inland city in China. Atmos. Chem. Phys. 2016, 16, 13807-13821. [CrossRef]

23. Zhang, C.; Ding, R.; Xiao, C.; Xu, Y.; Cheng, H.; Zhu, F.; Lei, R.; Di, D.; Zhao, Q.; Cao, J. Association between air pollution and cardiovascular mortality in Hefei, China: A time-series analysis. Environ. Pollut. 2017, 229, 790-797. [CrossRef] [PubMed]

24. Hu, R.; Liu, G.; Zhang, H.; Xue, H.; Wang, X.; Wang, R. Particle-associated Polycyclic Aromatic Hydrocarbons (PAHs) in the Atmosphere of Hefei, China: Levels, Characterizations and Health Risks. Arch. Environ. Contam. Toxicol. 2018, 74, 442-451. [CrossRef] [PubMed]

25. Xue, H.; Liu, G.; Zhang, H.; Hu, R.; Wang, X. Similarities and differences in $\mathrm{PM}_{10}$ and $\mathrm{PM}_{2.5}$ concentrations, chemical compositions and sources in Hefei City, China. Chemosphere 2019, 220, 760-765. [CrossRef] [PubMed]

26. Ward, J.H. Hierarchical grouping to optimize an objective function. J. Am. Stat. Assoc. 1963, 58, $236-244$. [CrossRef]

27. Draxler, R.R.; Hess, G.D. An overview of the HYSPLIT 4 modeling system for trajectories dispersion and deposition. Aust. Meteorol. Mag. 1998, 47, 295-308.

28. Wang, Y.Q.; Zhang, X.Y.; Draxler, R. TrajStat: GIS-based software that uses various trajectory statistical analysis methods to identify potential sources from long-term air pollution measurement data. Environ. Model. Softw. 2009, 24, 938-939. [CrossRef]

29. Nicolas, J.; Chiari, M.; Crespo, J.; Galindo, N.; Lucarelli, F.; Nava, S.; Yubero, E. Assessment of potential source regions of $\mathrm{PM}_{2.5}$ components at a southwestern Mediterranean site. Tellus B 2011, 63, 96-106. [CrossRef]

30. Burnett, R.T.; Pope, C.A.; Ezzati, M.; Olives, C.; Lim, S.S.; Mehta, S.; Shin, H.H.; Singh, G.; Hubbell, B.; Brauer, M.; et al. An integrated risk function for estimating the global burden of disease attributable to ambient fine particulate matter exposure. Environ. Health Perspect. 2014, 122, 397-403. [CrossRef]

31. Lin, C.; Lau, A.K.; Lu, X.; Fung, J.; Li, Z.; Li, C.; Wong, A.H. Assessing effect of targeting reduction of $\mathrm{PM}_{2.5}$ concentration on human exposure and health burden in Hong Kong using satellite observation. Remote Sens. 2018, 10, 2064. [CrossRef]

32. WHO. WHO Air Quality Guidelines for Particulate Matter, Ozone, Nitrogen Dioxide and Sulfur Dioxide Global Update 2005; World Health Organization: Geneva, Switzerland, 2006.

33. National Bureau of Statistics of China. China Statistical Yearbook (CSY), 2015 and 2016; National Bureau of Statistics of China: Beijing, China, 2015; ISBN 978-7-5037-7638-0.

34. Zhi, G.R.; Yang, J.C.; Zhang, T.; Guan, J.; Xue, Z.G. Rural household coal use survey, emission and policy implications. Res. Environ. Sci. 2015, 28, 1179-1185.

35. Sun, Y.; Zhuang, G.; Wang, Y.; Han, L.; Guo, J.; Dan, M.; Zhang, W.; Wang, Z.; Hao, Z. The air-borne particulate pollution in Beijing-concentration, composition, distribution and sources. Atmos. Environ. 2004, 38, 5991-6004. [CrossRef]

36. Acker, J.G.; Leptoukh, G. On line analysis enhances use of NASA earth science data. EOS Trans. Am. Geophy. Union 2007, 88, 14-17. [CrossRef]

37. Yin, X.; Foy, B.D.; Wu, K.; Feng, C.; Kang, S.; Zhang, Q. Gaseous and particulate pollutants in Lhasa, Tibet during 2013-2017: Spatial variability, temporal variations and implications. Environ. Pollut. 2019, 253, 68-77. [CrossRef]

38. Agudelo-Castaneda, D.M.; Teixeira, E.C.; Schneider, I.L.; Pereira, F.N.; Oliveira, M.L.S.; Taffarel, S.R.; Sehn, J.L.; Ramos, C.G.; Silva, L.F.O. Potential utilization for the evaluation of particulate and gaseous pollutants at an urban site near a major highway. Sci. Total Environ. 2016, 543, 161-170. [CrossRef]

39. Liu, F.; Zhang, Q.; Ronald, J.V.; Zheng, B.; Tong, D.; Yan, L.; Zheng, Y.X.; He, K.B. Recent reduction in $\mathrm{NO}_{\mathbf{x}}$ emissions over China: Synthesis of satellite observations and emission inventories. Environ. Res. Lett. 2016, 11, 114002. [CrossRef] 
40. Abeleira, A.A.; Farmer, D.K. Summer ozone in the northern front range metropolitan area: Weekend-weekday effects, temperature dependences and the impact of drought. Atmos. Chem. Phys. Discuss. 2017. [CrossRef]

41. Baudic, A.; Gros, V.; Sauvage, S.; Locoge, N.; Sanchez, O.; Sarda-Esteve, R.; Kalogridis, C.; Petit, J.E.; Bonnaire, N.; Baisnee, D.; et al. Seasonal variability and source apportionment of volatile organic compounds (VOCs) in the Paris megacity (France). Atmos. Chem. Phys. 2016, 16, 11961-11989. [CrossRef]

42. Wang, T.; Xue, L.; Brimblecombe, P.; Lam, Y.F.; Li, L.; Zhang, L. Ozone pollution in China: A review of concentrations, meteorological influences, chemical precursors, and effects. Sci. Total Environ. 2017, 575, 1582-1596. [CrossRef]

43. Li, G.; Bei, N.; Cao, J.; Wu, J.; Long, X.; Feng, T.; Dai, W.; Liu, S.; Zhang, Q.; Tie, X. Wide-spread and persistent ozone pollution in eastern China during the non-winter season of 2015: Observations and source attributions. Atmos. Chem. Phys. 2017, 17, 2759-2774. [CrossRef]

44. Chan, C.Y.; Xu, X.D.; Li, Y.S.; Wong, K.H.; Ding, G.A.; Chan, L.Y.; Cheng, X.H. Characteristics of vertical profiles and sources of $\mathrm{PM}_{2.5}, \mathrm{PM}_{10}$ and carbonaceous species in Beijing. Atmos. Environ. 2005, 39, 5113-5124. [CrossRef]

45. Choi, S.D.; Chang, Y.S. Carbon monoxide monitoring in Northeast Asia using MOPITT: Effects of biomass buringing and regional pollution in April 2000. Atmos. Environ. 2006, 40, 686-697. [CrossRef]

46. Jiang, J.K.; Zhou, W.; Cheng, Z.; Wang, S.X.; He, K.B.; Hao, J.M. Particulate matter distributions in Chian during a winter period with frequent polluton episodes (January 2013). Aerosol Air Qual. Res. 2015, 15, 494-503. [CrossRef]

47. Zhang, Y.L.; Cao, F. Fine particulate matter $\left(\mathrm{PM}_{2.5}\right)$ in Chian at a city level. Sci. Rep. 2015, 5, 14884. [CrossRef]

48. Apte, J.S.; Marshall, J.D.; Cohen, A.J.; Brauer, M. Addressing global mortality from ambient PM 2.5 . Environ. Sci. Technol. 2015, 49, 8057-8066. [CrossRef]

49. Liu, J.; Han, Y.; Tang, X.; Zhu, J.; Zhu, T. Estimating adult mortality attributable to $\mathrm{PM}_{2.5}$ exposure in China with assimilated $\mathrm{PM}_{2.5}$ concentrations based on a ground monitoring network. Sci. Total Environ. 2016, 568, 1253-1262. [CrossRef]

50. Hu, J.; Huang, L.; Chen, M.; Liao, H.; Zhang, H.; Wang, S.; Zhang, Q.; Ying, Q. Premature mortality attributable to particulate matter in China: Source contributions and responses to reductions. Environ. Sci. Technol. 2017, 51, 9950-9959. [CrossRef]

51. Nie, D.; Chen, M.; Wu, Y.; Ge, X.; Hu, J.; Zhang, K.; Ge, P. Characterization of fine particulate matter and associated health burden in Nanjing. Int. J. Environ. Res. Public Health 2018, 15, 602. [CrossRef] 